\title{
Recent advances in the recovery of tungsten values in the fine and ultrafine size range
}

\author{
PRADIP \\ Tata Research Development and Design Centre, 1 Mangaldas Road, Pune 411 050, India
}

\begin{abstract}
Recent advances in the design of fine gravity concentrators and high gradient magnetic separation devices have led to significant improvements in the recovery of tungsten values in tine and ultratine size range. Amongst the more promising techniques of fine particles processing. encouraging results are reported on froth flotation, shear flocculatuon and spherical agglomeration of tungsten ore slimes. Development of highly selective reagents such as alkyl hydroxamates, phosphonic acid derivatives and alkylated nitrosonapthols is vital for enhancing separation efficiencies in the slimes size range. Froth flotation of Indian tungsten ore stimes (partıcularly at Degana) using appropriate reagent combinations appears promising and needs to be examined in greater detail
\end{abstract}

Keywords. Tungsten ore slimes; fine particles processing; froth flotation; shear flocculation; spherical agglomeration; hydroxamates; nitroso-napthols; phosphonic acids.

\section{Introduction}

The characteristic properties of tungsten include high density, high melting point, a low coefficient of thermal expansion, high tensile strength at elevated temperatures, high corrosion resistance and good thermal and electrical conductivities. Its principal uses are in cemented carbides, alloy-steels, superalloys, electrical and electronic products and defence applications. India has limited and extremely low grade ore reserves of this important strategic metal.

The world reserves of tungsten metal in natural ores are estimated to be 3.5 million tonnes. More than $80 \%$ of known reserves of tungsten occur in just five countries China, which accounts for $43 \%$ of the total, former USSR, Canada, USA and Australia. In terms of annual production, China is the world leader, accounting for an estimated $32 \%$ of total world output (Harris and Humphreys 1983; Stafford 1985). In the absence of any reliable consumption figures for certain countries, the total annual consumption can only be estimated. The 1990 estimate of consumption was $44,300 \mathrm{t}$, a figure which has remained steady for the 1985-90 period, but declined in 1991 to $37,950 \mathrm{t}$, essentially due to the recession the world over (Mayby 1990). At the present rate of consumption (around 50,000 t/annum) and at an estimated figure of $70 \%$ recovery, the current tungsten reserves are just adequate for the next 50 years only, indicating a need to find new reserves as well as to utilize the available resources of this metal efficiently.

Wolframite $\left[(\mathrm{Fe}, \mathrm{Mn}) \mathrm{WO}_{4}\right]$ and scheelite $\left(\mathrm{CaWO}_{4}\right)$ are the two most common tungsten mineral constituents of economic ore deposits. The content of tungsten ores is typically less than $1 \% \mathrm{WO}_{3}$ (Yih and Wang 1981). In general, tungsten ores are beneficiated by crushing-grinding to liberation size followed by concentration involving gravity separation. fotation of sulphides, and magnetic and electrostatic separation where necessary. International trade practice requires tungsten concentrates to assay around $60-70 \% \mathrm{WO}_{3}$. 
India does not possess economical ore deposits of tungsten. Currently, tungsten ore concentrates are produced in the form of wolframite concentrate from Degana and as a scheelite concentrate from the gold ore tailings in Karnataka (Anon 1994). The state of the art review of present plant practice in India (Jakhu and Ray 1996; Rao 1996) indicates that more than $40 \%$ of tungsten values are being lost during beneficiation, as slimes. More specifically, the beneficiation flowsheets proposed for Degana plant, processing relatively richer quartz vein ore assaying $0 \cdot 2-0 \cdot 3 \% \mathrm{WO}_{3}$, project a recovery of around $60 \%$ at concentrate grade of $65 \% \mathrm{WO}_{3}$. It is therefore necessary that innovative means are found to recover tungsten values in relatively finer size range (minus 37 microns). Some of the promising fine particles processing techniques, particularly with reference to their applications in the recovery of tungsten values from Indian ore slimes, are reviewed in this paper.

\subsection{Fine particles processing}

All separation processes are sensitive to particle size and typically exhibit a preferred size range for maximum separation efficiency. In general, surface forces become predominant (as compared to inertial forces) with decreasing particle size. As a consequence, the separation techniques based on differences in surface properties of minerals, either natural or induced by a variety of selective reagents, are found more effective than gravity separation, magnetic or electrostatic separation. Froth flotation is the most widely used technique for the concentration of finely disseminated ores. It has been observed however, that fine particles below 10 microns size are difficult to float. The selectivity is adversely affected at fine sizes due to low collision efficiencies with gas bubbles and mechanical entrainment of fines in the froth. Due to small mass, low momentum and large surface area of fines, problems such as high reagent consumption, excessive froth stabilization, loss in reagent selectivity, slime coating, rapid oxidation and higher dissolution rates, make the flotation separation more difficult (Fuerstenau 1980). A variety of innovative means have been developed during the past two decades to overcome some of the above mentioned problems and thus enhance separation efficiency of fine particles.

Several variations of froth flotation process have been evolved, which extend the particle size range of flotation separation to finer sizes. Among the modified flotation techniques, one can include high temperature flotation, column flotation, oil flotation, electroflotation, agglomerate flotation/shear flocculation, selective flocculation-flocc flotation, spherical agglomeration and carrier flotation. Most of these techniques are aimed at preferential aggregation of fine particles using selective surfactants, polymers, oil or even coarse carrier particles. Relatively bigger aggregates can then be separated by conventional froth flotation, elutriation, oil phase separation and magnetic separation. Several of these fine particles processes are schematically illustrated in figure 1. The readers are referred to comprehensive reviews by Fuerstenau (1980), Somasundaran (1986) and a recent monograph edited by Laskowski and Ralston (1992), for details of these techniques. Some of the above-mentioned techniques have been tried on tungsten ore slimes also. For instance, in addition to conventional froth flotation with more selective reagents, shear flocculation and spherical agglomeration have been successfully employed to achieve separation of scheelite and wolframite minerals from associated gangue. The results reported in the literature on tungsten cre slimes are 


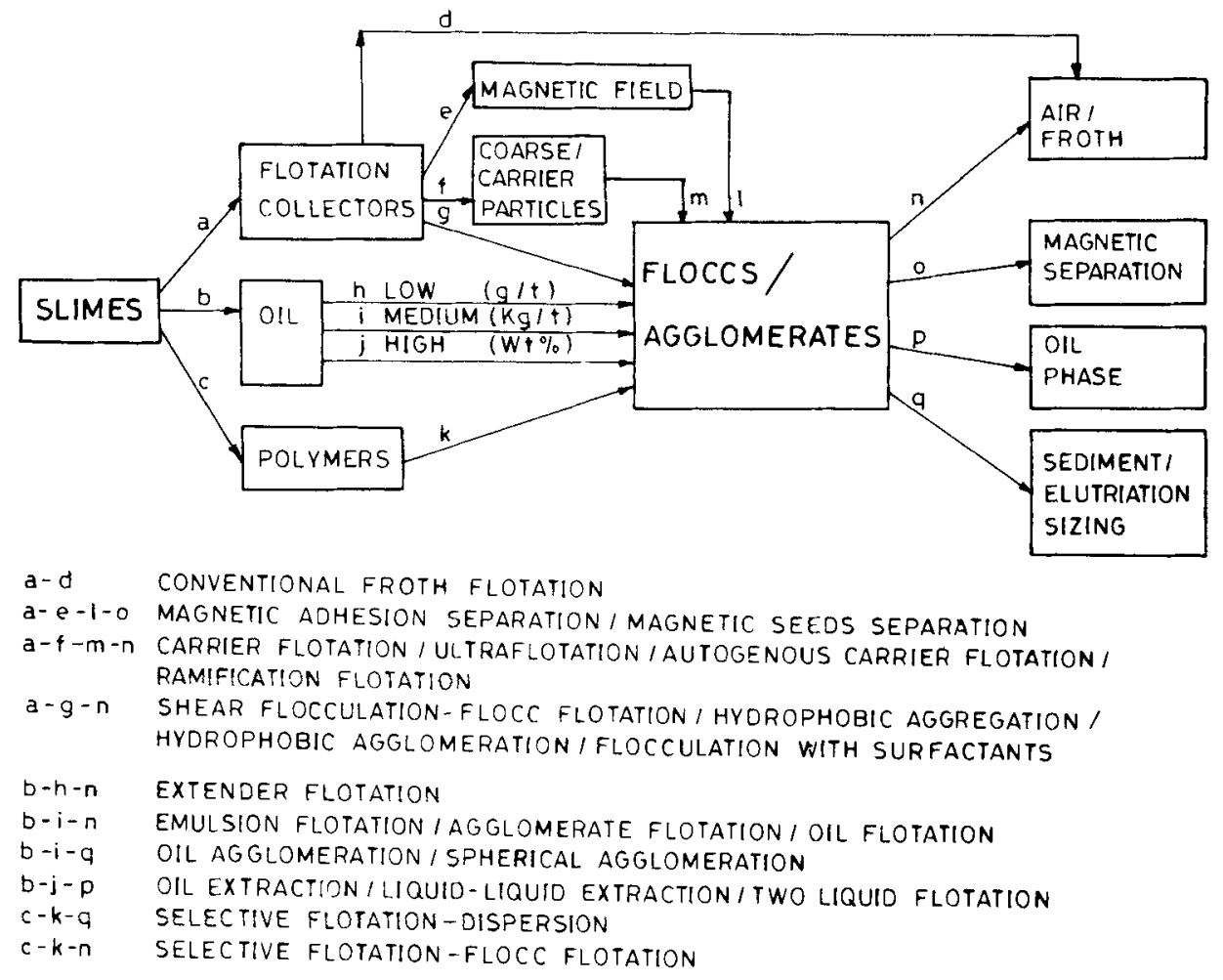

Figure 1. Schematic diagram showing different fine particles processing techniques.

reviewed in the following section. Promising results achieved with new designs of gravity separators (for heavy fines) and magnetic separation (weakly magnetic slimes containing wolframite) devices in order to concentrate on tungsten ore slimes are also discussed.

\section{Gravity concentration}

Until recently, it was thought that gravity separation was not possible for particles finer than 50 microns. However, while the efficiency of separation does decrease with particle size, the separation of very fine heavy minerals has been successfully demonstrated on an industrial scale using modern gravity separation devices. Burt (1984) has recently reviewed the range of commercial gravity concentration equipment available for finer separation. Amongst these, Bartles Mozley separator and Bartles Mozley crossbelt separator are reported to be very efficient for the beneficiation of tin and tungsten ore slimes, as illustrated in table 1.

A typical size-wise recovery characteristics of these separators for tin-tungstentantalum type ores is shown in figure 2 . The finest size of particles recovered by any of the units is $\sim 5$ microns, which is also consistent with the theoretical analysis of these devices (Burt 1984). The most suitable upper size limit for a slime treatment circuit is 45-53 microns. 
Table 1. A comparative performance of various fine gravity concentrators on similar tin ores (after Burt 1988).

\begin{tabular}{lrrrrr}
\hline & \multicolumn{2}{c}{ Assay $\%$} & & & \\
Equipment & Feed & Conc. & $\begin{array}{c}\text { Recovery } \\
(\%)\end{array}$ & $\begin{array}{c}\text { Enrichment } \\
\text { ratio }\end{array}$ & Capacity* \\
\hline Vanner & 0.58 & 4.95 & 19.0 & 8.53 & 0.67 \\
Denver Buckman & 0.81 & 4.01 & 40.0 & 4.95 & $10-80$ \\
BM separator & 0.49 & 1.52 & 70.0 & 3.10 & 12.40 \\
YT centrifugal & 0.40 & 1.10 & 80.0 & 2.75 & 13.00 \\
Crossbelt conc. & 0.36 & 31.76 & 52.5 & 88.20 & 1.30 \\
GEC duplex & 0.34 & 10.51 & 51.3 & 30.91 & 4.00 \\
Rocking vanner & 0.34 & 11.00 & 68.0 & 32.90 & 0.35 \\
Spiral sluice & 0.31 & 6.77 & 40.0 & 21.80 & 48.00 \\
Slime table & 0.35 & 13.37 & 55.4 & 38.20 & 0.87 \\
\hline
\end{tabular}

* Capacity in tons per day per square meter of floor space

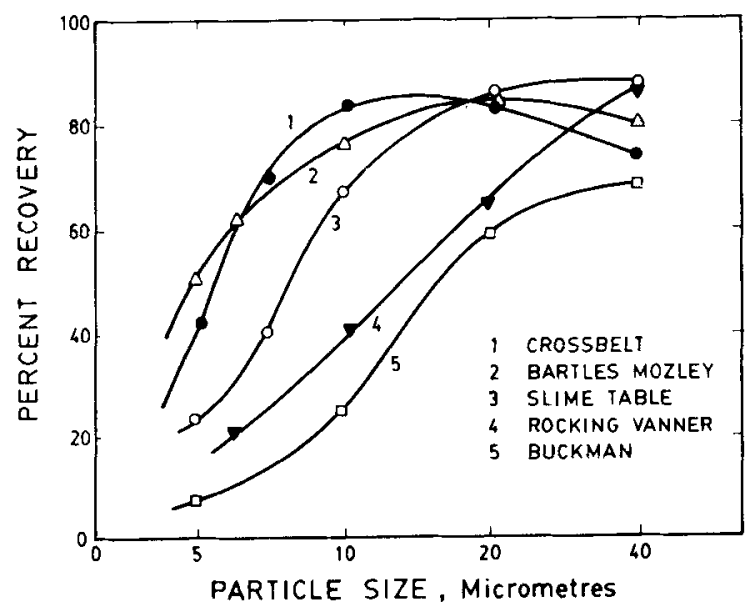

Figure 2. Recovery-size relationship for some fine gravity separation devices (After Burt 1984).

According to Burt (1984), the following parameters are crucial in optimizing the operation of fine gravity concentrators:

Machine parameters: Frequency and amplitude of shear, deck slope, residence time (cycle time or belt speed), cóncentrate removal method, feed width, deck surface, rotation speed (for centrifugal separation), surface roughness.

Solids characteristics: Particle size distribution and top size, amount of slimes, particle shape, relative density of heavies and lights, degree of liberation.

Pulp characteristics: Solids content (pulp density), flow rate, $\mathrm{pH}$, viscosity, cation concentration, volume of wash water.

Bartles Mozley separators are being used very effectively at Panasqueira, Portugal and at Chojilla in Bolivia for preconcentration of tungsten ores. The Tajishan mill in China employs rocking shaking vanners for recovery of tungsten values from slimes; 
Enramada in Bolivia uses the cross belt concentrator (Burt 1984). A recently introduced separator known as the multi-gravity separator (MGS) uses high ' $\mathrm{g}$ ' forces to improve the concentration of fine heavy minerals. Mozley and Childs (1992) have reported successful use of small diameter hydrocyclones in conjunction with MGS at Wheat Jane Tin Mine in Cornwall. UK. The tin cleaner concentrate in the plant which was previously treated in a column flotation cell is now being concentrated in a Double Drum MGS leading to an overall increase in tin recovery.

Clemente et al (1993) have reported encouraging results of MGS gravity separation on ultraîne plant slimes containing wolframite from Beralt Tin and Wolfram Operations at Minas da Panasqueira in Portugal. From a slimes sample assaying $0.3 \%$ $\mathrm{WO}_{3}$ (containing much of wolframite in -25 microns fraction), it appeared possible to produce a wolframite concentrate of $50 \% \mathrm{WO}_{3}$ at a reasonable recovery of around $60 \%$, using a three-stage gravity separation (MGS) with intermediate sulphide flotation step. A new device known as the rocking shaking vanner has been reported to be quite efficient for concentrating tungsten and tin ore slimes in China. The lower size limit for effective separation is 20 microns. It can also be used to recover fine tungsten values entrapped in sulfide froth during the beneficiation of wolframite containing ores (Chin et al 1981). Chen and $\mathrm{Xu}(1980)$ have reported on the utility of a centrifugal separator for beneficiating wolframite slimes. Operational recoveries in centrifugal separator were found to be of the order of 58-80\% at an enrichment ratio of 4.4-5.7. Lower size limit for effective separation is reported as 10 microns. The capacities of the units employed in China are 14-19 tons/day.

\section{Magnetic separation}

Paramagnetic properties of wolframite are determined by the presence of iron and manganese whereas scheelite is nonmagnetic. The recovery of wolframite from slimes by a combination of flotation and magnetic separation is practised at several plants around the world (Svoboda 1987). High gradient magnetic separation (HGMS) (sometimes also called wet high intensity magnetic separation (WHIMS)) units are used to achieve the final grade of wolframite concentrate. For example, Gak et al (1983) obtained a product containing $21 \% \mathrm{WO}_{3}$ it it recovery of $79 \%$ following a process flowsheet which involved wolframite flotation inlowed by HGMS separation on the concentrate.

Sun et al (1984) have reported on HGMS in improving the performance of a beneficiation flowsheet for wolframite slimes as illustrated in figure 3 and table 2 . The authors also reported the size-wise recovery and en richment ratio achieved during the concentration of wolframite slimes by HGMS. It appears that the separation is not as efficient both at coarser and finer sizes as in the intermediate size range (figure 4). The enrichment ratio is however dependent on the proportion of other weakly magnetic materials such as tourmaline, limonite and siderite present in the ore slimes. Laboratory magnetic separation tests indicated recoveries of upto $87 \%$ of $\mathrm{WO}_{3}$ at enrichment ratios of 4 to 20. The results of pilot plant tests and full scale plant trials shown in table 2 confirmed the utility of HGMS in concentration of wolframite slimes. As shown in figure 3, wolframite concentrate obtained from HGMS can be further upgraded by the flotation process. Wolframite was floated with arsonic acid in the plant, which yielded a concentrate grade of $51 \% \mathrm{WO}_{3}$ at a recovery of $95 \%$, starting from a feed assaying $6.9 \% \mathrm{WO}_{3}$ only. 


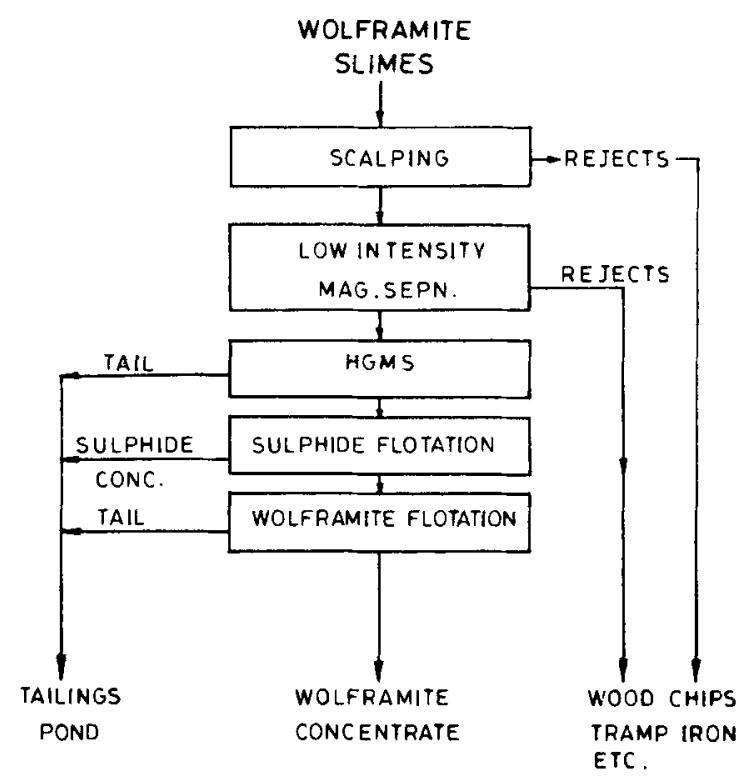

Figure 3. A schematic flowsheet showing beneficiation scheme for wolframite slurries in China (After Sun et al 1984).

Table 2. Metallurgical performance of HGMS circuit for wolframite slimes; Flowsheet shown in figure 3 (after Sun et al 1984).

\begin{tabular}{lcc}
\hline Assay $\left(\% \mathrm{WO}_{3}\right)$ & Pilot plant test & Full scale production \\
\hline Feed & 0.51 & 0.42 \\
Concentrate & 47.7 & $35 \cdot 4$ \\
Tail & 0.12 & 0.12 \\
Recovery & 72.8 & 73.8 \\
\hline
\end{tabular}

Similarly, at Puquio Cocha plant in Peru, a flowsheet incorporating HGMS, shaking tables, bulk sulphide flotation, followed by high intensity dry magnetic separation is adopted in order to recover wolframite values from the accumulated plant tailings containing $0 \cdot 15 \% \mathrm{WO}_{3}$. A final concentrate assaying $66 \% \mathrm{WO}_{3}$ at an overall recovery of $55 \%$ is obtained (Wells 1986).

\section{Flotation of tungsten minerals}

A majority of large scale scheelite producers in the world are using flotation separation (Leaver and Royer 1938; McLaren 1942; Mitchell et al 1951; Babok and Viduetskii 1967; Auge et al 1975; Hanna and Somasundaran 1976; Vazquez et al 1976; Yongxin and Changger 1983; Hoefer et al 1989). Scheelite ore bodies are generally of the contact metasomatic type having relatively finer liberation size. Common collectors for scheelite flotation are oleic acid, mixed oleic-linoleic acid, sodium oleate, tall oil, saponified tall oil and fatty acids mixture. $\mathrm{pH}$ varies typically from 9-10.5, depending upon the depressant, dispersant and the temperature used during flotation. Sodium 


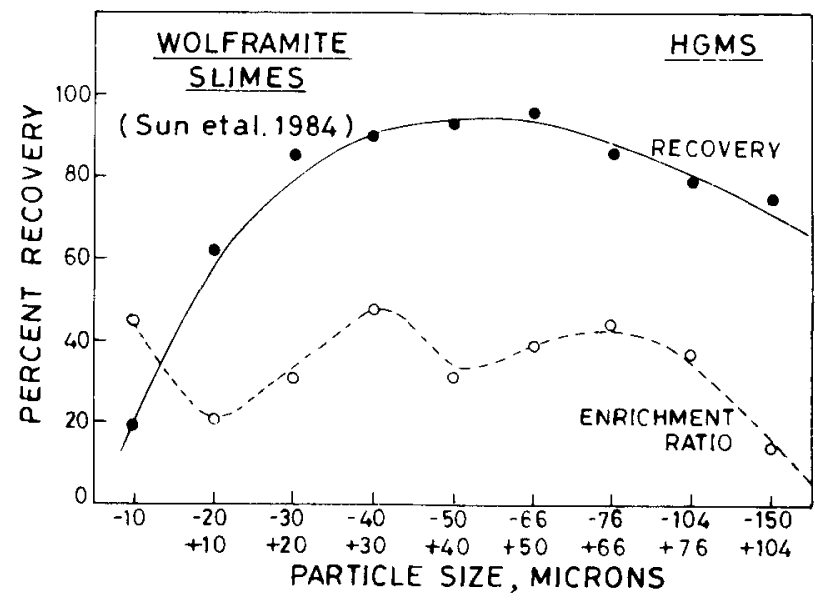

Figure 4. Recovery-size relationship for the beneficiation of wolframite slimes during HGMS circuit (Data taken from Sun et al 1984).

silicate is a common depressant/dispersant. Separation of scheelite from calcite is more difficult. Polyvalent cations such as $\mathrm{Fe}^{2+}$ have been found effective for depressing calcite during flotation in presence of sodium silicate depressant (Yih and Wang 1981). Tannin, quebracho, formic and lactic acids are common calcite depressants for scheelite flotation.

A more recent process developed by Union Carbide for the selective flotation separation of scheelite from a low grade (approx. $0.5 \% \mathrm{WO}_{3}$ ) tungsten ore containing appreciable quantities of both calcareous (calcite and fluorite) and silicate gangue minerals, involves conditioning of the ore pulp with judicious amounts of lime, followed by soda ash and sodium silicate as modifiers followed by flotation of scheelite using a mixture of oleic and napthenic acids as collector (Vazquez et al 1976). Maximum selectivity index was obtained when $0.9 \mathrm{~kg} / \mathrm{t}$ of lime and $4 \mathrm{~kg} / \mathrm{t}$ of sodium silicate were used for the beneficiation of a scheelite ore from Tempiute, Nevada (USA), which was three times larger than in the absence of lime. These results were confirmed with another scheelite ore sample from Brazil. Scheelite concentrates assaying $50-56 \% \mathrm{WO}_{3}$ could be produced with this process with recoveries of the order of $95 \%$, starting with a feed assiaying $1.2 \% \mathrm{WO}_{3}$.

The selectivity of $\beta$-octyl amine ethyl phosphonic acid (ONP) in the scheelite/fluorite/ barite system has been established by $\mathrm{Hu}$ and Wang (1991). Its chemical structure is:

$$
\mathrm{C}_{8} \mathrm{H}_{17} \mathrm{NH}-\mathrm{C}_{2} \mathrm{H}_{4}-\stackrel{\mathrm{O}}{\mathrm{O}} \mathrm{C}_{\mathrm{OH}}^{\mathrm{OH}}
$$

Scheelite fines have been floated from a synthetic admixture with quartz by Rao and Charan (1991) with sodium alkyl sulfosuccinate (Porocoll SC-30) and sodium oleate. The results are shown in figure 5. It is interesting to note that spherical agglomeration experiments using kerosene and the same two reagents show similar results. Oleate exhibits peak performance in the alkaline range whereas sulfosuccinate is most effective in the acidic range. These authors also report encouraging results on a sample of low grade gold tailings containing scheelite from Kolar Gold Fields (KGF), India. From a feed assaying $0 \cdot 15 \% \mathrm{WO}_{3}$, a concentrate assaying as high as $13 \% \mathrm{WO}_{3}$ could be 


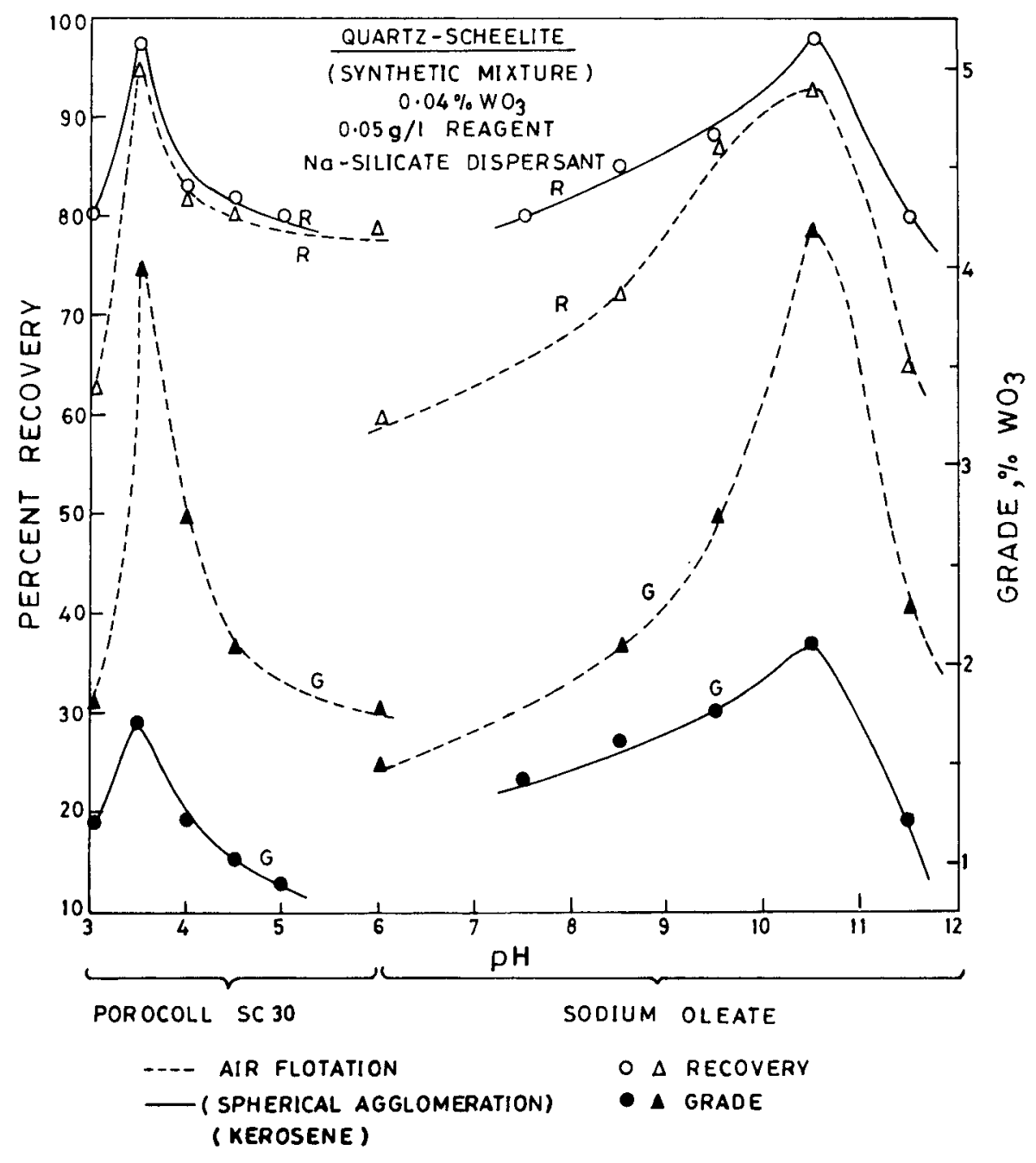

Figure 5. Spherical agglomeration (solid lines) and froth flotation (dotted lines) separation of scheelite fines from its synthetic mixtures with quartz using sodium oleate (alkaline $\mathrm{pH}$ ) and sulfosuccinate (Porocoll SC-30 in acidic pH) reagents (Data taken from Rao and Charan 1991).

produced at an overall recovery of $90 \%$, by spherical agglomeration process. Flotation of the same ore with oleate at $\mathrm{pH} 10.5$ yielded a rougher concentrate assaying $4 \% \mathrm{WO}_{3}$ at a recovery of $95 \%$. It could be upgraded to $14 \% \mathrm{WO}_{3}$ in one cleaning step with an overall recovery of $90 \%$. Similar results could be obtained with Porocoll at pH 3.5.

Polyvalent metal-silicate hydrosols as dispersant--depressants have been reported to exhibit excellent results during scheelite flotation, particularly for more difficult separation of scheelite from calcareous gangue (calcite, apatite and fluorite). Based on his extensive work, Mercade (1983) provided the following ranking of the various metal-hydrosols for scheelite flotation:

$$
\mathrm{Fe}^{++}=\mathrm{Co}^{++}>\mathrm{Be}^{++}>\mathrm{Al}^{+++}>\text {sodium silicate alone. }
$$

His flotation results are summarized in table 3. 
Table 3. Flotation experiments with metal-silicate hydrosol on a run-of-mine scheelite ore assaying 0.9\% $\mathrm{WO}_{3}$ (after Mercade 1983).

\begin{tabular}{|c|c|c|c|}
\hline & \multicolumn{3}{|c|}{ Concentrate } \\
\hline Experimental & $\mathrm{Wt} \%$ & Assay $\% \mathrm{WO}_{3}$ & Recovery \% \\
\hline $\begin{array}{l}\text { Separate addition of sodium } \\
\text { silicate and } \mathrm{FeSO}_{4} .7 \mathrm{H}_{2} \mathrm{O}\end{array}$ & $\begin{aligned} &-. . \\
& 5.9\end{aligned}$ & 154 & 43.2 \\
\hline $\begin{array}{l}\text { Hydrosol prepared by adding } \\
5 \% \text { solution of } \mathrm{Na} \text { silicate to } \\
1 \% \text { solution of } \mathrm{FeSO}_{4} .7 \mathrm{H}_{2} \mathrm{O}\end{array}$ & $1 \cdot 0$ & $68 \cdot 9$ & 76.9 \\
\hline Standard preparation* & $1 \cdot 3$ & $63 \cdot 2$ & $92 \cdot 7$ \\
\hline
\end{tabular}

*1. Grinding $98 \%-200$ mesh: $\mathrm{Na}_{2} \mathrm{CO}_{3} 5 \mathrm{~kg} / \mathrm{t}$; Sodium silicate $2.5 \mathrm{~kg} / \mathrm{t}$; Conditioning time 15 min.; Flotation $\mathrm{pH}$ 10: Flotation time $5 \mathrm{~min}$.; 3 times cleaning; Oleic acid $0.1 \mathrm{~kg} / \mathrm{t}$; Frother (Monamid $150 \mathrm{ADD}$ ) $0.4 \mathrm{~kg} / \mathrm{t}$ : $500 \mathrm{~g}$ sample, Denver sub A cell

2. Adding under continuous stirring, $1 \%$ solution of polyvalent salt to a $5 \%$ solution of sodium silicate.

Similar results have been reported by Oliveira and Sampaio (1988) on the flotation separation of Brazilian scheelite fines where the joint addition of sodium silicate and $\mathrm{FeSO}_{4} \cdot 7 \mathrm{H}_{2} \mathrm{O}$ in a $5 / 1$ ratio enhanced the selectivity of separation significantly. The collector used was Aero-promoter 845 (sulphosuccinamate). Fuerstenau and Fitzgerald (1990) also found a $3 \%$ increase in the recovery of scheelite with addition of aluminium silicate hydrosol (added in 3:1 ratio of silicate to aluminium) with oleic acid collector at pH6. Other reagents which have been found effective depressants in the flotation of tungsten ores include fluorosilicates, dichromates, phosphates, phosphoric/phosphorous acids, EDTA, polyacrylamides, various chelating agents, derivatives of valeric acid and alginate based depressants (Marinakis and Kelsall 1987c).

\subsection{Wolframite flotation}

The flotation of ores containing wolframite is not very common as it is not as responsive to flotation as scheelite. Besides conventional reagents like oleic acid/ oleate, alkyl sulphates and sulphonates, several other collectors such as alkyl hydroxamates, alkyl sulphosuccinamates, arsonic acids, phosphonic acids and napthols have been tried for the flotation of wolframite containing ores (Matsuev 1966; Koltunova et al 1971; Myasnikova and Krasnikova 1971; Kelsall and Marinakis 1984). A brief summary of the effectiveness of various important classes of reagents based on the reported literature is presented in the following sections.

\subsection{Oleic acid and sodium oleate}

Common fatty acid collectors containing oleic acid, linoleic acids have been used for wolframite flotation. Microflotation tests (Mukai 1962; Vishwanathan and Majumdar 1972) on wolframite with oleate (Houot 1965; Abeidu 1974, 1975; Itoh and Okada 1980; 

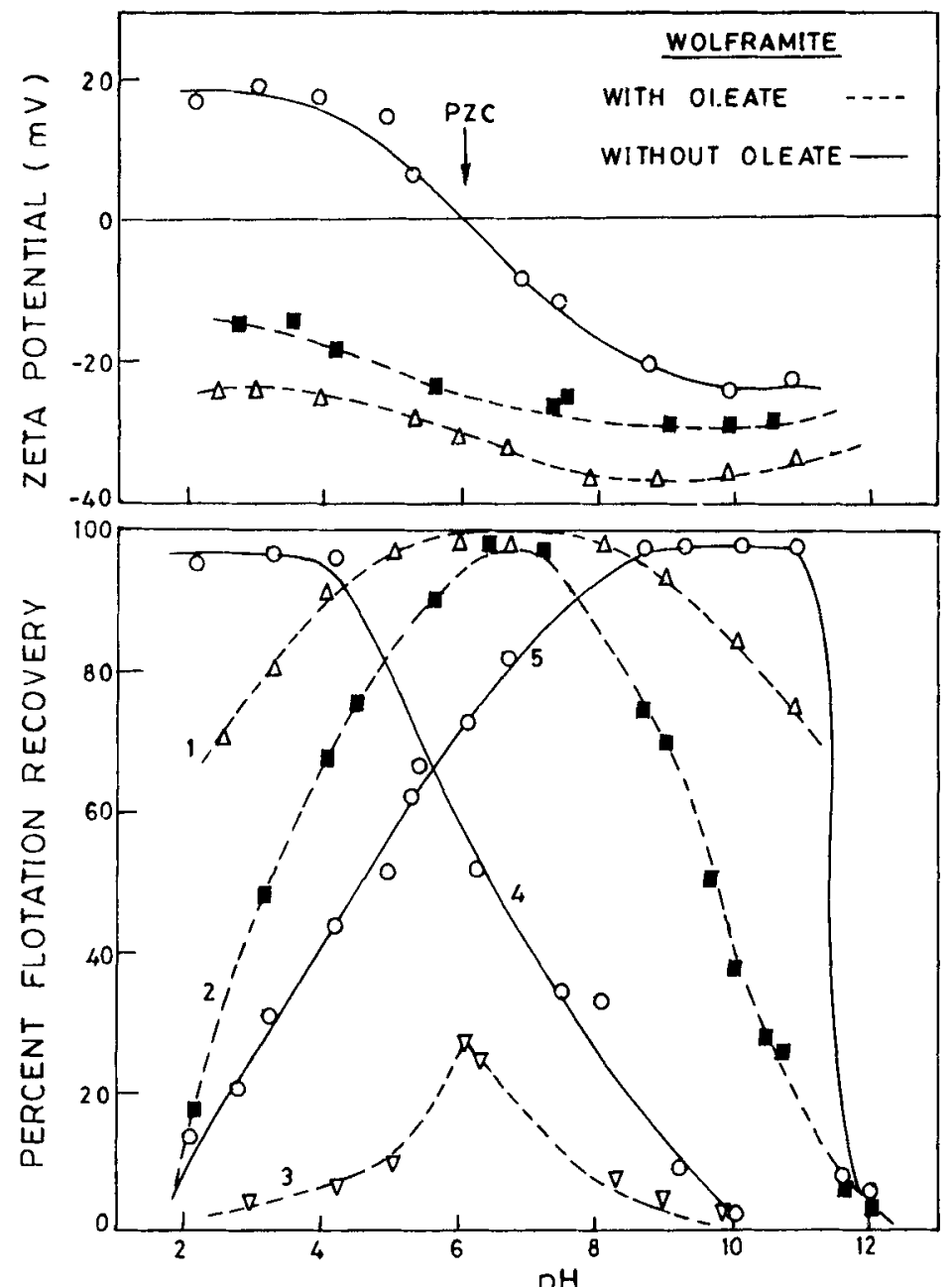

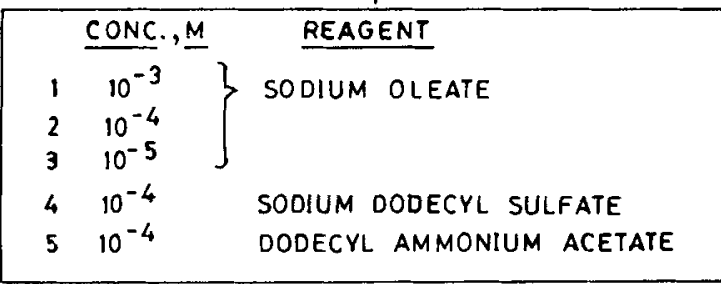

Figure 6. Micro-flotation of wolframite slimes with anionic (sodium oleate and sodium dodecyl sulfate) and cationic (dodecyl ammonium acetate) collectors; results of electrokinetic studies on wolframite with and without oleate adsorption are shown in the figure, indicating chemisorption of oleate. (Data taken from Woo and Whang 1986).

Woo and Whang 1986; Pradip 1991), alkyl sulphates and cationic amine collectors indicate that oleate chemisorbs on the wolframite surface. Anionic collectors like sulphonates and sulphates, however, adsorb on positively charged (below the zero point of charge of wolframite at $\mathrm{pH} \mathrm{6.1)} \mathrm{wolframite} \mathrm{and} \mathrm{cationic} \mathrm{collectors} \mathrm{like}$ dodecylamine on negatively charged surface ( $\mathrm{pH}$ above $\mathrm{PZC}$ ) as illustrated in figure 6. 


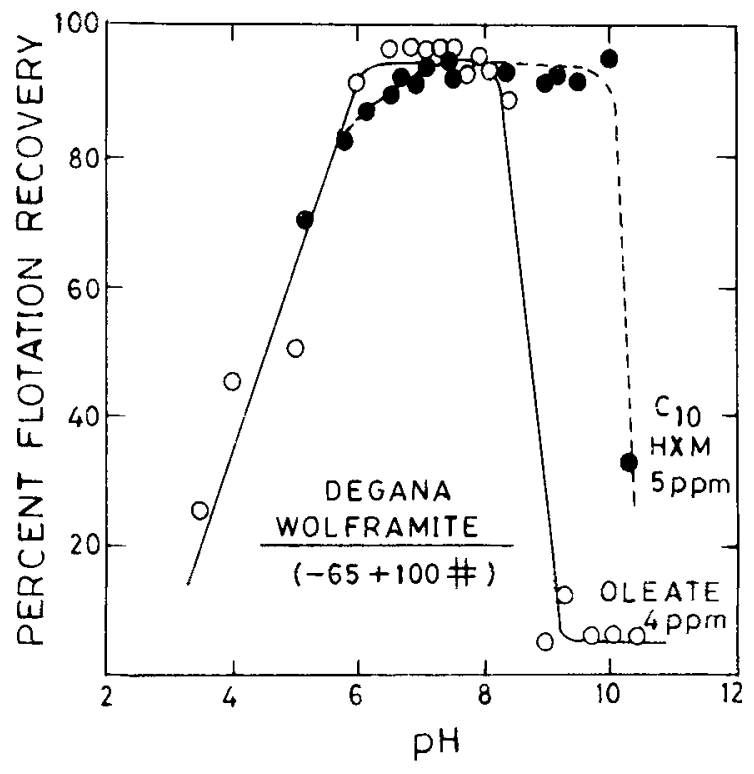

Figure 7. Hallimond tube flotation of wolframite slimes from Degana, India using sodium oleate and potassium decyl hydroxamate collectors: Effect of $\mathrm{pH}$ (After Pradip and Choudhuri i 991 ).

The low floatability of wolframite, coupled with relatively high floatability of fluorite makes selective flotation in natural ores without certain modifiers and regulators almost impossible. Hydrofluoric acid pretreatment of ore is found beneficial for enhancing selectivity (Bogdanov et al 1974; Abeidu 1975). Sodium hexametaphosphate is reported to be a good selective depressant for fluorite and cassiterite during wolframite flotation (Abeidu 1974, 1975). The concentration of constituent $\mathrm{Fe}^{2+}$, $\mathrm{Mn}^{2+}$ and $\mathrm{WO}_{4}^{2-}$ ions determines the zeta potential of wolframite and hence its floatability. $\mathrm{Fe} / \mathrm{Mn}$ ratio of wolframite also influences its flotation response with oleate collectors.

The $\mathrm{pH}$ range for flotation of wolframite using oleate collector lies between $\mathrm{pH} \mathrm{6-8,}$ as shown in figures 6 and 7 . Golikov et al (1986) recommend $C_{12}-C_{18}$ fatty acids mixtures for the flotation of wolframite and scheelite from complex refractory ores. Gak et al (1985) recovered wolframite from a gravity concentration slimes sample assaying $0 \cdot 12-0 \cdot 3 \% \mathrm{WO}_{3}$ and $0 \cdot 11-0 \cdot 16 \%$ Mo by two-stage flotation followed by magnetic separation. The first stage involved separation of sulfide minerals using xanthate $(0 \cdot 14 \mathrm{~kg} / \mathrm{t})$ and kerosene $(0 \cdot 10-0 \cdot 15 \mathrm{~kg} / \mathrm{t})$ collector at $\mathrm{pH} 8\left(\mathrm{Na}_{2} \mathrm{CO}_{3}\right.$ as $\mathrm{pH}$ modifier). The tails from the first flotation stage were refloated at $\mathrm{pH} 8$ with oleic acid $(0.6 \mathrm{~kg} / \mathrm{t})$ and kerosene $(0.5 \mathrm{~kg} / \mathrm{t})$ collector at a dosage of $0.05 \mathrm{~kg} / \mathrm{t}$ of sodium silicate depressant. Overall recovery enhancement due to this procedure was of the order of $10 \%$.

Extensive work carried out at Mekhanobr Institlite. Moscow indicates the important role played by the sodium fluosilicate depressant, particularly with the high temperature conditioning at $70-80^{\circ} \mathrm{C}$ in the presence of a depressant which desorbs oleic acid from the surfaces of gangue minerals so as to achieve better grades during cleaning stages (Plaksin et al 1967). 
Table 4. Flotation of wolframite slimes with alkyl hydroxamates reagent IM-50 (Data taken from Bogdanov et al 1974).

\begin{tabular}{|c|c|c|c|}
\hline \multirow[b]{2}{*}{ Process } & \multicolumn{2}{|c|}{ Assay $\% \mathrm{WO}_{3}$} & \multirow[b]{2}{*}{ Recovery $\%$} \\
\hline & Feed & Conc. & \\
\hline \multicolumn{4}{|l|}{$\begin{array}{l}\text { Primary flotation circuit } \\
\text { IM- } 50200 \mathrm{~g} / \mathrm{t}\end{array}$} \\
\hline $\begin{array}{l}\text { Sodium fluosilicate } 80 \mathrm{~g} / \mathrm{t} \\
\mathrm{pH} \sim 6 \\
\text { (Rougher plus } 2 \text { cleanings) }\end{array}$ & 0.43 & 9 & 93 \\
\hline \multicolumn{4}{|l|}{ Concentrate upgrading circuit } \\
\hline $\begin{array}{l}\mathrm{IM}-50200 \mathrm{~g} / \mathrm{t} \\
\mathrm{pH} \leqslant 1 \cdot 5 \\
\text { (Hydrochloric acid medium) }\end{array}$ & 9 & $24^{*}$ & $\begin{array}{c}90 \\
\text { (overall } \\
75 \% \text { ) }\end{array}$ \\
\hline
\end{tabular}

*Assay could be raised to $35 \% \mathrm{WO}_{3}$ with removal of magnetite (with a recovery loss of only $1 \%$ )

\subsection{Alkyl hydroxamates}

Hydroxamic acids and their salts are found to be more selective than fatty acids in the beneficiation of a variety of ores such as those containing iron, rare-earths, tin and tungsten minerals (Bogdanov et al 1974; Pradip 1981, 1990; Fuerstenau and Pradip 1984; Pradip and Fuerstenau 1991). Alkyl hydroxamates known as IM-50 in former USSR and consisting of a mixture of $\mathrm{C}_{7-9}$ hydroxamates are reported to be excellent collectors for tungsten. For wolframite flotation with IM-50, sodium fluosilicate was used since sodium silicate produced a pronounced depressing effect on wolframite group minerals. The experimental conditions and the results obtained on a sample of wolframite slimes from the gravity concentration circuit are summarized in table 4 . A comparison of oleate and hydroxamate collectors on a wolframite sample from Degana, India is shown in figure 7. The $\mathrm{pH}$ range for maximum flotation seems to be slightly more alkaline for hydroxamate. It is interesting to note that $\mathrm{C}_{10}$ hydroxamate is as effective a collector as a $\mathrm{C}_{18}$ oleate. In case of ores containing fluorite, however, slightly acidic $\mathrm{pHs}$ are recommended for achieving maximum selectivity (Bogdanov et al 1974).

Recent results reported by Wang et al (1986) on the flotation with hydroxamates of wolframite specimens containing $74.6 \%$ and $71.5 \% \mathrm{WO}_{3}$ having a $\mathrm{Mn} / \mathrm{Fe}$ ratio of 1.20 and 6.36 respectively, indicated that the flotation efficiency is enhanced at higher $\mathrm{Mn} / \mathrm{Fe}$ ratio. Maximum flotation recoveries were obtained in the $\mathrm{pH}$ range 6.5-8.5. Koval (1982) in former USSR has reported on the flotation separation of a complex wolframitescheelite ore by a flowsheet involving sulfide flotation with thiol collectors followed by magnetic separation to remove iron minerals followed by flotation with sodium oleate to remove sericite and chlorite and finally a combined flotation of tungsten minerals with reagent IM-50 (hydroxamates). A concentrate assaying as high as $48.5 \% \mathrm{WO}_{3}$ could be produced at a recovery of $84 \%$. Similarly flotation of gravity plant tailing with sodium napthene hydroxamate at $\mathrm{pH} 7-8$ with a reagent dosage of $300 \mathrm{~g} / \mathrm{t}$ and flotation time of 20-25 minutes, followed by wet magnetic separation of the concentrate yielded a satisfactory product (Berger et al 1982; Gak et al 1983). Wolframite concentrate assaying $16-28 \% \mathrm{WO}_{3}$ could thus be obtained using hydroxamate collectors from the tailings 
and wastes assaying $0 \cdot 08-0 \cdot 38 \% \mathrm{WO}_{3}($ Gak et al 1981). Tiunov et al (1980) report the use of a combination of fatty acids and hydroxamate collectors at $\mathrm{pH} 8-9$ in the presence of oxalic acid as a depressant (sodium carbonate as a modifier). Pradip (1991) also found that the combination of fatty acids and alkyl hydroxamates is an efficient collector for flotation of wolframite ore slimes with hydrofluoric acid pretreatment.

\subsection{Arsonic acids}

p-Tolyl arsonic acid has been known for a long time as a selective collector for cassiterite. Its structure is shown below:<smiles>Cc1ccc([As](=O)(O)O)cc1</smiles>

It was first used industrially in the mid-fifties and by the early seventies it was being employed for tin flotation at several plants around the world (Senior and Poling 1986). The major concern with arsonic acid collectors is their relative toxicity and the tailings disposal problems. Arsonic acids based flotation collectors have been extensively used in the flotation of wolframite ores in China (Li et al 1980; Zhu and Jiang 1983, 1986; Zhu and Zhu 1984; Hu and Li 1989). Methyl benzyl arsonic acid was found to be more effective collector than benzyl arsonic acid both for cassiterite as well as wolframite slimes. Slimes containing $0.33 \% \mathrm{WO}_{3}$ could be upgraded to $39 \cdot 5 \% \mathrm{WO}_{3}$ at a recovery of $85 \%$ with arsonic acid collectors.

\subsection{Phosphonic acids}

Recognizing that arsonic acids, although specific collectors for cassiterite and wolframite, were toxic, considerable research efforts were devoted to identify related compounds that would be less toxic and less expensive than arsonic acids. Kirchberg and Wottgen (1967) synthesized and evaluated a range of phosphonic acid compounds and found $p$-ethylphenylene phosphonic acid of the following chemical structure:<smiles>CCc1ccc(P(=O)(O)O)cc1</smiles>

was comparable to arsonic acids in terms of flotation efficiency. Collins and coworkers (1984) examined alkyl phosphonic acids and found them less expensive, though also less selective than aryl phosphonic acids for the flotation of tin ores. $p$-Styryl phosphonic acid known as SPA and having the following structure:<smiles>O=P(O)(O)C=Cc1ccccc1</smiles>

is a commercial flotation reagent which is being used industrially in many plants around the world (Bilsing et al 1985; Gruner and Bilsing 1989, 1992). 
Kotlyarevsky et al (1984) reported on the development and commercialization of diphosphonic acid collectors known as Flotol reagents. These diphosphonic acid derivatives are used in the beneficiation of a wide variety of ores such as phosphate, tungsten, tin, fluorite and oxidized sulphide ores of base metals in the former USSR. The commercial reagent Flotol-7,9 whose main active compound is 1-hydroxyalkylidene-1,1 diphosphonic acid, has the following structure:<smiles>[R]C(O)(P(=O)(O)O)P(=O)(O)O</smiles>

Collins et al (1984) carried out extensive work with alkyl imino-bis-methylene phosphonic acids (structure shown below) as collectors for a variety of minerals including

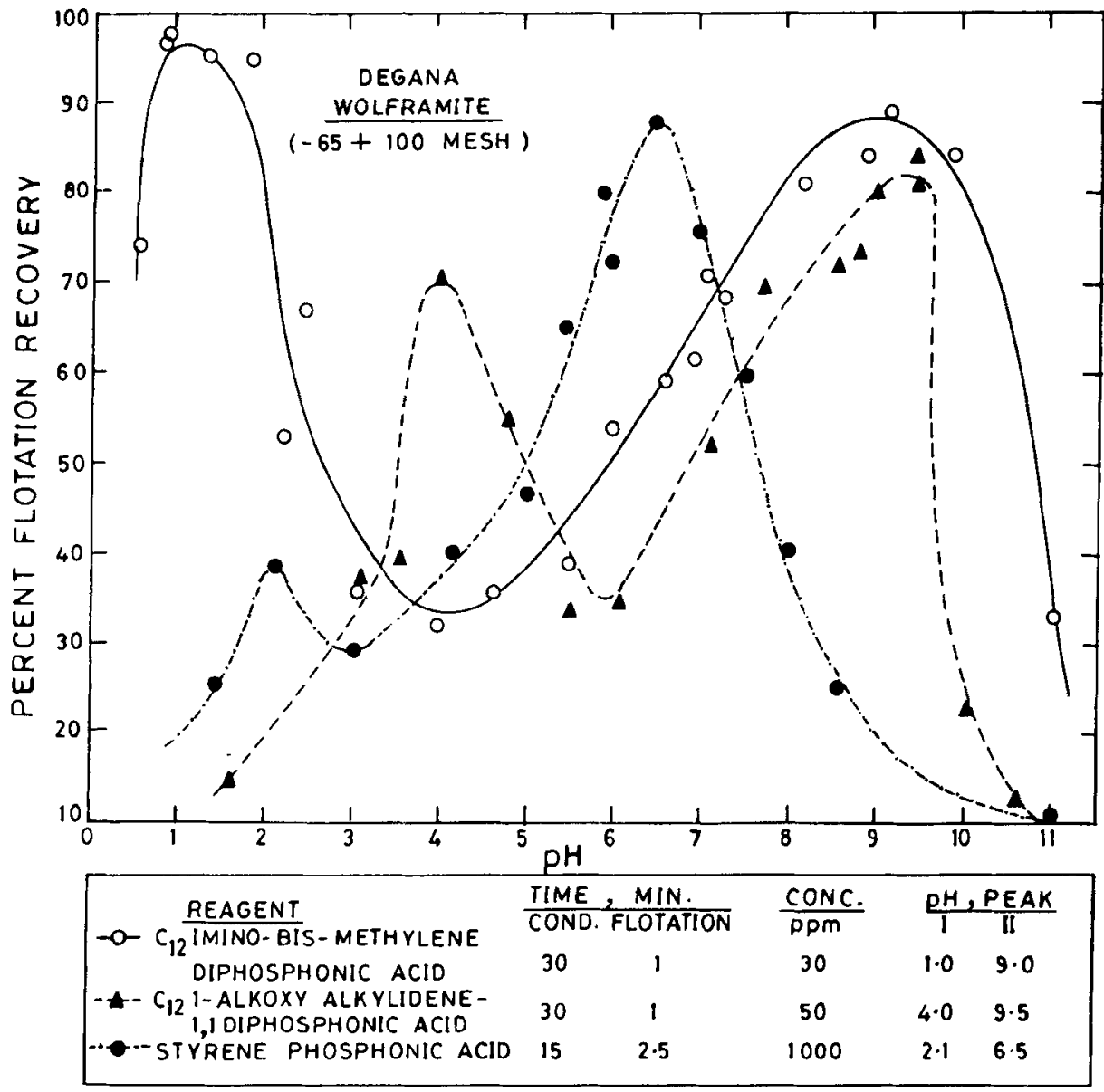

Figure 8. Effect of the molecular architecture of the reagents based on phosphonic acid functional group on the micro-flotation of wolframite slimes from Degana, India (After Pradip and Choudhuri 1996 ). 
wolframite.<smiles>[R]N(CCP(=O)(O)O)CP(=O)(O)O</smiles>

Batch flotation results indicate that the $n$-octyl compound of the above structure is an efficient collector for tungsten minerals. The preferred $\mathrm{pH}$ range for maximum selectivity against gangue minerals like garnet, tourmaline, chlorite and quartz is $7-8 \cdot 5$. Zhu and Xiao (1989) found tetradecyl imino-bis methyl phosphonic acid (FXL-14) to be an efficient flotation reagent for wolframite flotation.

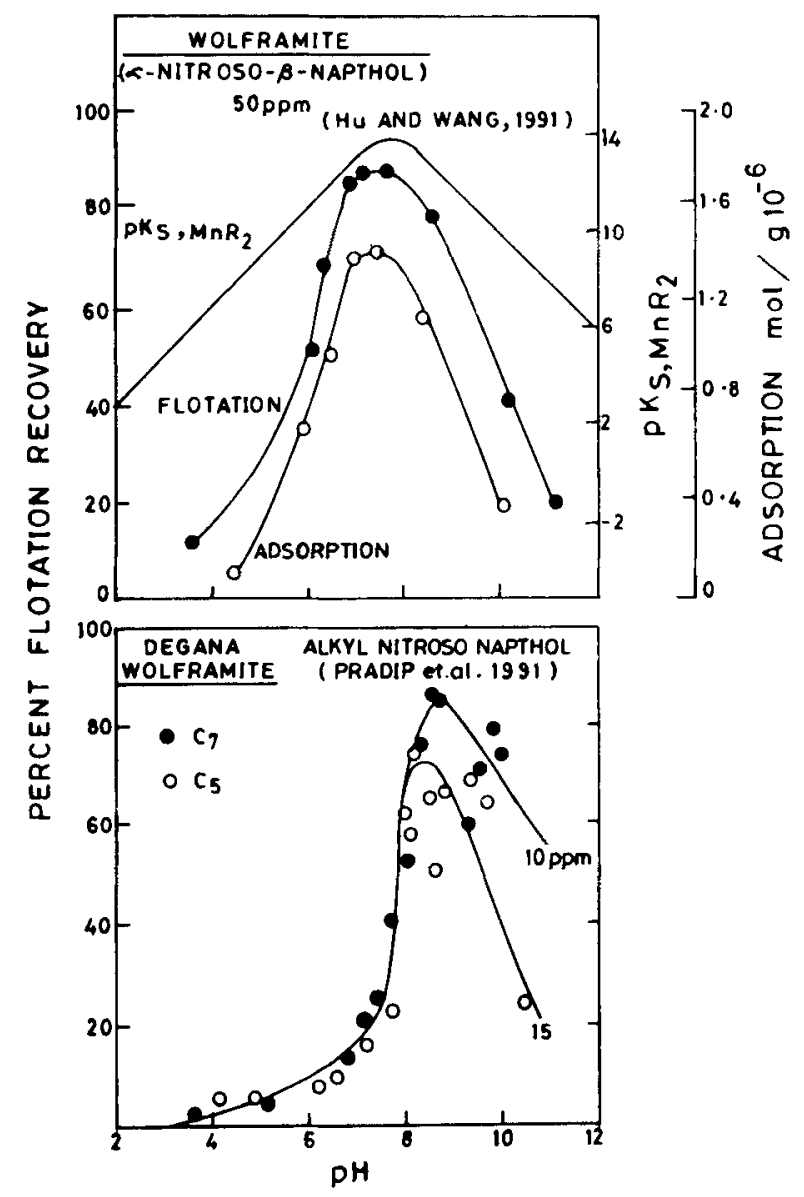

Figure 9. A comparison of results on the flotation of wolframite with alkyl nitrosonapthols (data taken from Pradip and Choudhuri 1991b) and pure $\alpha$-nitroso- $\beta$-napthol (data taken from $\mathrm{Hu}$ and Wang 1991 ) reagents. 
Pradip and Chaudhuri (1991) have recently investigated a variety of phosphonic acid collectors for the flotation of wolframite. A comparison of three kinds of phosphonic acid derivatives for the flotation of Degana wolframite as illustrated in figure 8 , indicates that the $\mathrm{pH}$ range of maximum flotation recovery is sensitive to the chemical structure of the collector. Interestingly, the commercial SPA reagent was not as effective (both with respect to kinetics as well as dosage) as the other two, namely Flotol and alkyl-bis-methylene derivatives. Alkyl imino-bis methylene diphosphonic acids exhibited excellent flotation recoveries in the acidic $\mathrm{pH}$ range $(\mathrm{pH}<2)$ also.

\subsection{Alkyl sulphosuccinamates}

Sulphosuccinamate collectors were first synthesized by American Cyanamid Co. in late 1940s. Subsequently it was found to be an excellent collector for cassiterite flotation. It is marketed by Cyanamid under the trade name Aero Promoter A845. The commercial reagent Aerosol 22 also has similar structure. These collectors have been widely used in Bolivian tin flotation plants at pH below 2.5 (Senior and Poling 1986). Even though alkyl sulphosuccinamate collectors should also float wolframite, there is only limited published literature available regarding its use and efficacy particularly the selectivity aspects in the flotation of tungsten ores.

\subsection{Alkyl nitroso-napthols}

Because of their excellent chelating properties with heavy metal ions, nitroso- $\beta$-napthols are very widely used in analytical chemistry. Plaksin et al (1967) reported the synthesis of nitroso alkylated $\beta$-napthol reagents $\left(\mathrm{C}_{8}-\mathrm{C}_{12}\right.$ carbon chain) for the flotation of tungsten ores. Laboratory test results indicated that as compared to conventional oleic acid collectors which rarely gave a concentration ratio of more than 5 to 6 for tungsten ores, it was possible with alkylated napthols, to achieve enrichment ratio of about 20 .

Extensive work carried out by Pradip and Chaudhuri (1991) on the synthesis, characterization, testing and evaluation of alkylated napthols (structure as shown below) indicates that napthol based derivatives could be excellent flotation collectors for wolframite.<smiles>[R]C(=O)c1ccc2c([N+](=O)[O-])c(O)ccc2c1</smiles>

Two such reagents, namely with $\mathrm{C} 5$ and $\mathrm{C} 7$ chain lengths respectively, were used to float a wolframite sample from Degana, India. The results are shown in figure 9 along with the results reported by $\mathrm{Hu}$ and Wang (1991) on the flotation of wolframite with $\alpha$-nitroso- $\beta$-napthol (without alkylation). In addition to the significantly lower reagent dosages required with alkylated napthols, it is also worth noting that the preferred $\mathrm{pH}$ range for maximum flotation recovery shifts to slightly more alkaline range with alkylated reagent. The $\mathrm{pH}$ of maximum flotation recovery appears to correspond with the $\mathrm{pH}$ of maximum formation of corresponding $\mathrm{Mn}$ complexes, suggesting strong chelation, as anticipated. 


\section{Shear flocculation}

It has long been known that in the presence of long chain collectors, there is selective aggregation of collector coated hydrophobic particles in the flotation cell leading to faster flotation kinetics of relatively finer particles. This effect whereby ultrafine particles are made to aggregate under a shear field of sufficient magnitude (optimum agitation) through a surfactant of adequate chain length (hydrophobicity) was given the name "shear flocculation" by Warren $(1975 \mathrm{a}, \mathrm{b})$ essentially to distinguish it from the other well known aggregation processes, for example, coagulation by electrolytes and flocculation by soluble polymers. More recently, in literature various authors have used other terms for the same or related phenomena, such as 'selective aggregation', 'hydrophobic agglomeration', 'controlled dispersion-shear flocculation', 'hydrophobic aggregation'. The 'carrier flotation', 'ultraflotation autogenous or ramification carrier flotation', 'slime coating' also refer to the related phenomenon where coarse carrier mineral particles (alternatively coarser particles of the same mineral) cause aggregation of finer particles under certain conditions of agitation intensity and hydrophobicity of coarse and fine particles. For a detailed discussion of the surface chemistry and the principles underlying this phenomenon, the readers are referred to recent reviews on the process (Subrahmanyam and Forssberg 1990; Bhaskar Raju et al 1991; Warren 1992).

Some of the promising results obtained on the possibility of employing this technique to the beneficiation of tungsten minerals are presented in the following paragraphs. It is worth emphasizing that some of the parameters controlling shear flocculation include particle hydrophobicity (collector dosage and nature of collector), shear rate (agitation intensity), particle surface charge (influenced by $\mathrm{pH}$ and dispersants), particle size, particle concentration (pulp density), flocculation time, feed grade, and relative sizes of coarse and fine particles (size distribution).

Warren $(1975 \mathrm{a}, \mathrm{b})$ working with ultrafine scheelite particles, having a wide size distribution (mixtures of 1 micron and 10 40 microns size fractions) observed that in the presence of oleate, aggregation between coarse and fines occurred at lower stirring speeds than the aggregation between ultrafines alone. The particle size distribution of flocculated pulps exhibited bimodal behaviour indicating flocculation of finer particles (Warren 1982; Koh et al 1986). A pilot plant test comprising grinding, classification, shear flocculation followed by flotation of scheelite ore from King Island, Tasmania, having up to $70 \mathrm{wt} \%$ less than 15 microns indicated that rougher flotation recovery was increased from $74 \%$ to $83 \%$ and the concentrate grade from 5 to $6 \% \mathrm{WO}_{3}$ as a result of shear flocculation step before flotation. The value of extra tungsten recovered was as high as four times the incremental running cost of shear flocculation equipment (Warren 1982).

$\mathrm{Hu}$ et al (1988) have coined a new term called 'autogenous carrier flotation/ramification carrier flotation' process for similar effects observed by them in the flotation of

Table 5. A comparison between conventional and autogenous carrier flotation on a tungsten ore (after Hu et al 1988).

\begin{tabular}{lccc}
\hline \multicolumn{3}{c}{ Assay $\% \mathrm{WO}_{3}$} & \\
Process & Feed & Concentrate & Recovery (\%) \\
\hline Conventional flotation & 0.30 & $21 \cdot 8$ & 44.2 \\
Autogenous carrier flotation & 0.31 & 28.1 & $59 \cdot 1$ \\
\hline
\end{tabular}




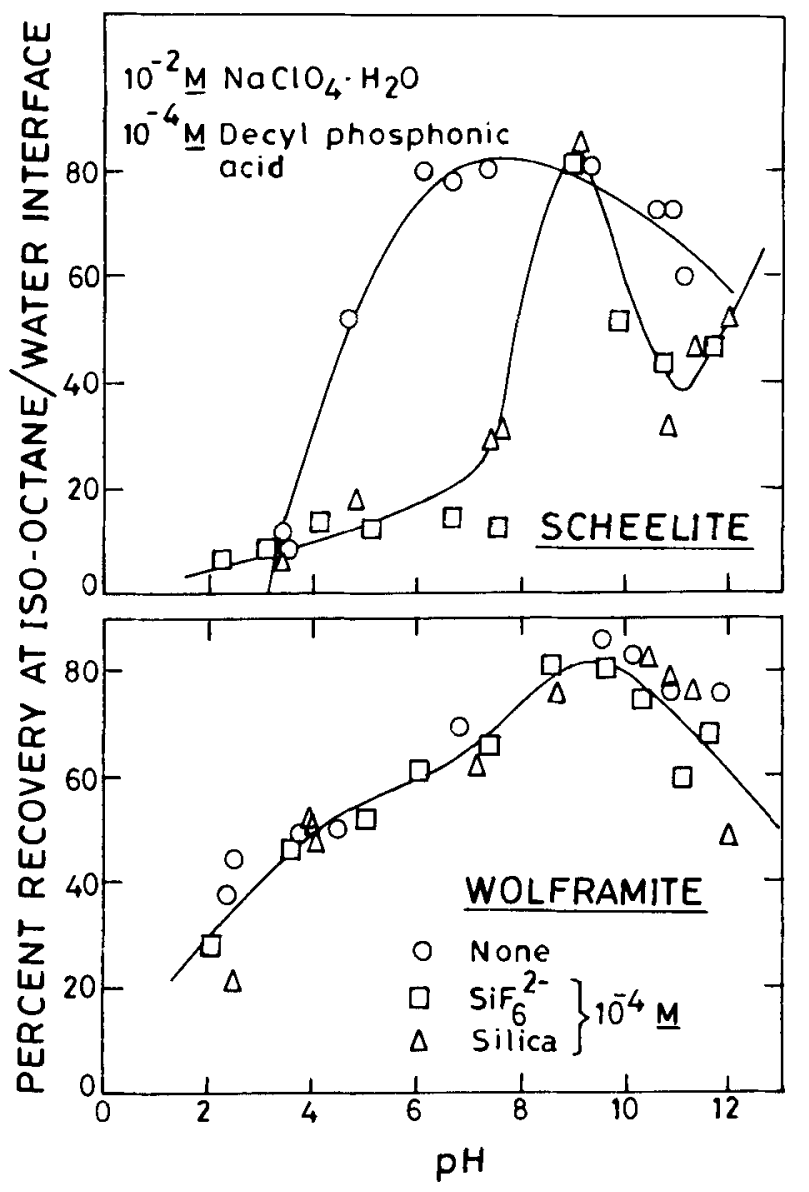

Figure 10. Effect of fluorosilicate and silicate species on the recovery of scheelite and wolframite at iso-octane/water interface in presence of $\mathrm{NaClO}_{4} \cdot \mathrm{H}_{2} \mathrm{O}$ electrolyte and decyl phosphonic acid collector (After Marinakis and Kelsall 1987c).

wolframite (tungsten ore slimes) with sodium oleate collector. In this process ultrafine 5 micron wolframite particles were successfully recovered using coarser reagentized wolframite as carrier. For an unevenly disseminated ore, it involves the classification of flotation feed in coarse and slimes followed by flotation of slimes using coarse fraction concentrate as a carrier. It is interesting that Singh et al (1992) report similar effects observed during the flotation of phosphate ore slimes with oleate collector. The results obtained on the flotation of an ore containing wolframite are illustrated in table 5 . The role of metal ions like $\mathrm{Ca}^{2+}$ and $\mathrm{Fe}^{3+}$ in activating wolframite during hydrophobic agglomeration with sodium oleate collector has also been investigated by Dawei et al (1986, 1987).

\section{Two liquid flotation/spherical agglomeration}

Flotation of very fine particles (less than 10 microns) is not very efficient. Another process which aims to overcome this problem is spherical agglomeration. It is similar to 


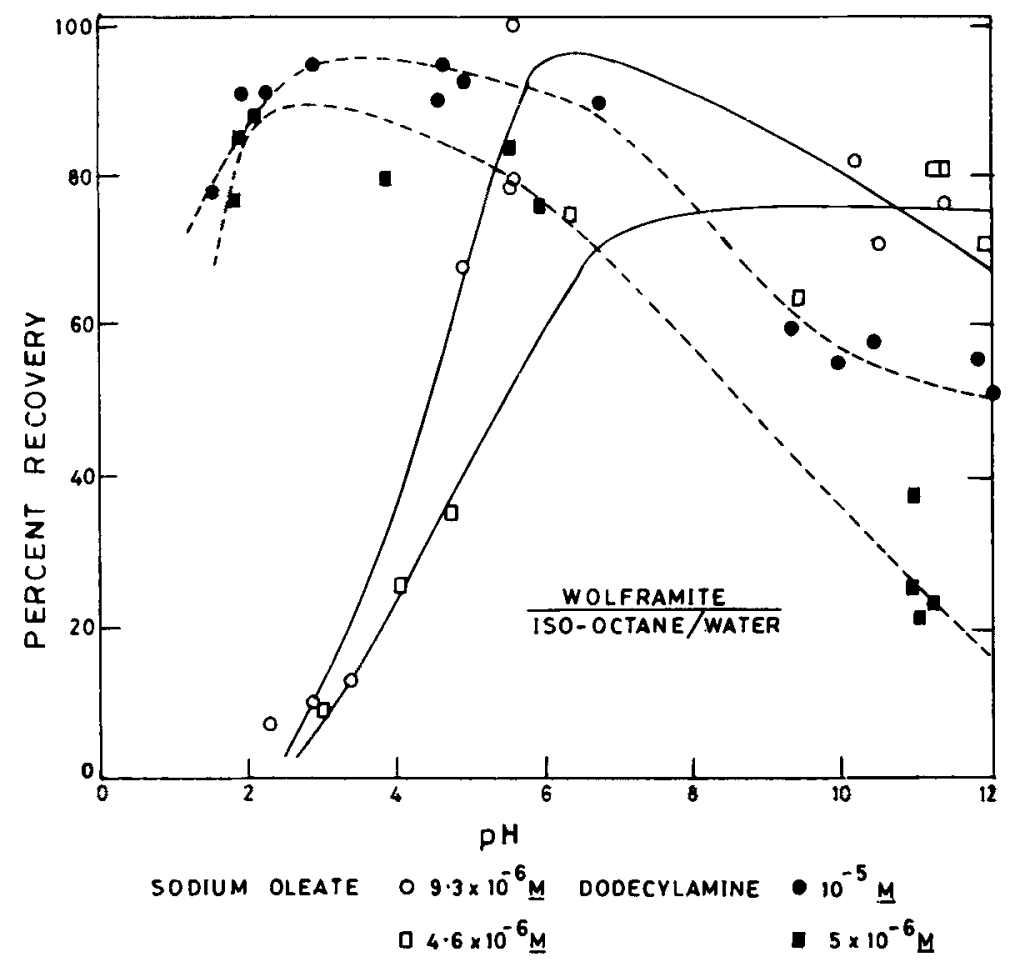

Figure 11. Effect of $\mathrm{pH}$ on the concentration of wolframite at iso-octane/water interface with oleate (alkaline) and dodecylamine (acidic) as collectors respectively (After Kelsall and Marinakis 1984).

flotation, that is, the surface chemistry of separation as well as the need to find selective surfactants to make them hydrophobic (oleophilic) is similar except that oil droplets are used to separate the minerals in this process instead of air bubbles. Once the optimum selectivity in terms of hydrophobicity of particles is achieved with the help of appropriate surfactants, an immiscible organic phase (an oil) is introduced in the aqueous suspension, causing bridging between the hydrophobic particles and binding them into agglomerates. With an increase in the amount of bridging oil, the agglomerates change from unconsolidated flocs to large densified spheres, in which $40-80 \%$ of the void spaces are occupied by bridging liquid. These agglomerates can be screened and separated.

Extensive work was carried out by Kelsall and coworkers (Kelsall and Marinakis 1984; Marinakis and Kelsall 1985, 1987a, b, c; Kelsall and Pitt 1987) on the spherical agglomeration of wolframite, scheelite and other gangue minerals like calcite, topaz, feldspar, tourmaline, and quartz. A number of surfactants such as sodium dodecyl sulfate, sodium oleate, dodecylamine, dodecyl phosphonic acid, and alkyl iminobis-methylene phosphonic acid (Briquest reagents) were used. The results indicated that the separation of tungsten minerals from the associated gangue is feasible by a spherical agglomeration process using decyl phosphonic acid as a collector at alkaline $\mathrm{pH}$ values in the presence of either sodium silicate or fluorosilicate depressant. Scheelite separation requires strict $\mathrm{pH}$ control at $\mathrm{pH} 9$ (figure 10). The surface chemistry of separation is illustrated in figure 11. Maximum concentration of -13.6 
micron wolframite particles occurs at isooctane/water interface in the $\mathrm{pH}$ range 6-10 and 2-6 with oleic acid-sodium oleate and dodecylamine collectors respectively (figure 11). The proposed mechanism of adsorption of oleic acid on wolframite involves precipitation of iron and manganese oleates on the surface. On the other hand, dodecylamine adsorption is attributed to the formation of tungstate-amine complex on the surface.

\section{Degana wolframite slimes}

Since there is as yet no commercial plant for the beneficiation of tungsten ore in India, it is difficult to obtain a representative sample of slimes for research and development efforts. Under a research programme sponsored by the Department of Mines, New Delhi, India, Tata Research Development and Design Centre (TRDDC), Pune in collaboration with National Chemical Laboratory (NCL), Pune and Department of Chemistry, University of Jodhpur, recently conducted extensive investigations to establish possible process methodologies for the recovery of tungsten values from slimes that are likely to be generated as and when the proposed beneficiation plant at Degana is commissioned. Two samples of Degana ore, namely one from the settled slimes available in the water ponds at Degana denoted as "Degana Plant Slimes" and the other obtained from the Ore Dressing Section, Bhabha Atomic Research Centre (BARC), represented as "Granite Ore Preconcentrate" were used in these investigations.

It is important to note that since till now no grinding has ever been carried out in the plant, the Degana plant slimes accumulated on site over the years do not represent the tailings slimes that are likely to be generated when the regular beneficiation plant is commissioned. As discussed later in this paper, there is therefore a significant proportion of values in these slimes which can best be recovered during gravity separation stage itself. "Granite Ore Preconcentrate", on the other hand, is more representative of the slimes which are likely to be generated during granite ore processing at Degana. This sample was produced at BARC starting from an ore sample assaying 0.04-0.05\% $\mathrm{WO}_{3}$. The ore was ground to $90 \%-150$ mesh, subjected to wet high intensity magnetic separation (WHIMS) for the separation of topaz as nonmagnetics; then floated for the separation of lithium containing mica (as concentrate). The flotation

Table 6. Mineralogy of typical Degana ore samples.

\begin{tabular}{lcc}
\hline Mineral & $\begin{array}{c}\text { Quartz vein lode } \\
\left(0.27 \% \mathrm{WO}_{3}\right)\end{array}$ & $\begin{array}{c}\text { Granite ore } \\
\left.0.04-0.05 \% \mathrm{WO}_{3}\right)\end{array}$ \\
\hline Quartz and feldspar & $76 \cdot 2$ & 62.5 \\
Mica & $10 \cdot 9$ & $23 \cdot 4$ \\
Topaz & $9 \cdot 6$ & $13 \cdot 5$ \\
Iron oxide minerals & 0.8 & $0 \cdot 2$ \\
Transparent minerals & $1 \cdot 2$ & 0.2 \\
$\quad$ (Fluorite, calcite, zircon, & & \\
$\quad$ monazite, tourmaline etc.) & $1 \cdot 3$ & 0.2 \\
Opaque minerals & & \\
$\quad$ (Ilmenite, pyrite, pyrrhotite, & & \\
$\quad$ chalcopyrite, wolframite etc.) & & \\
\hline
\end{tabular}



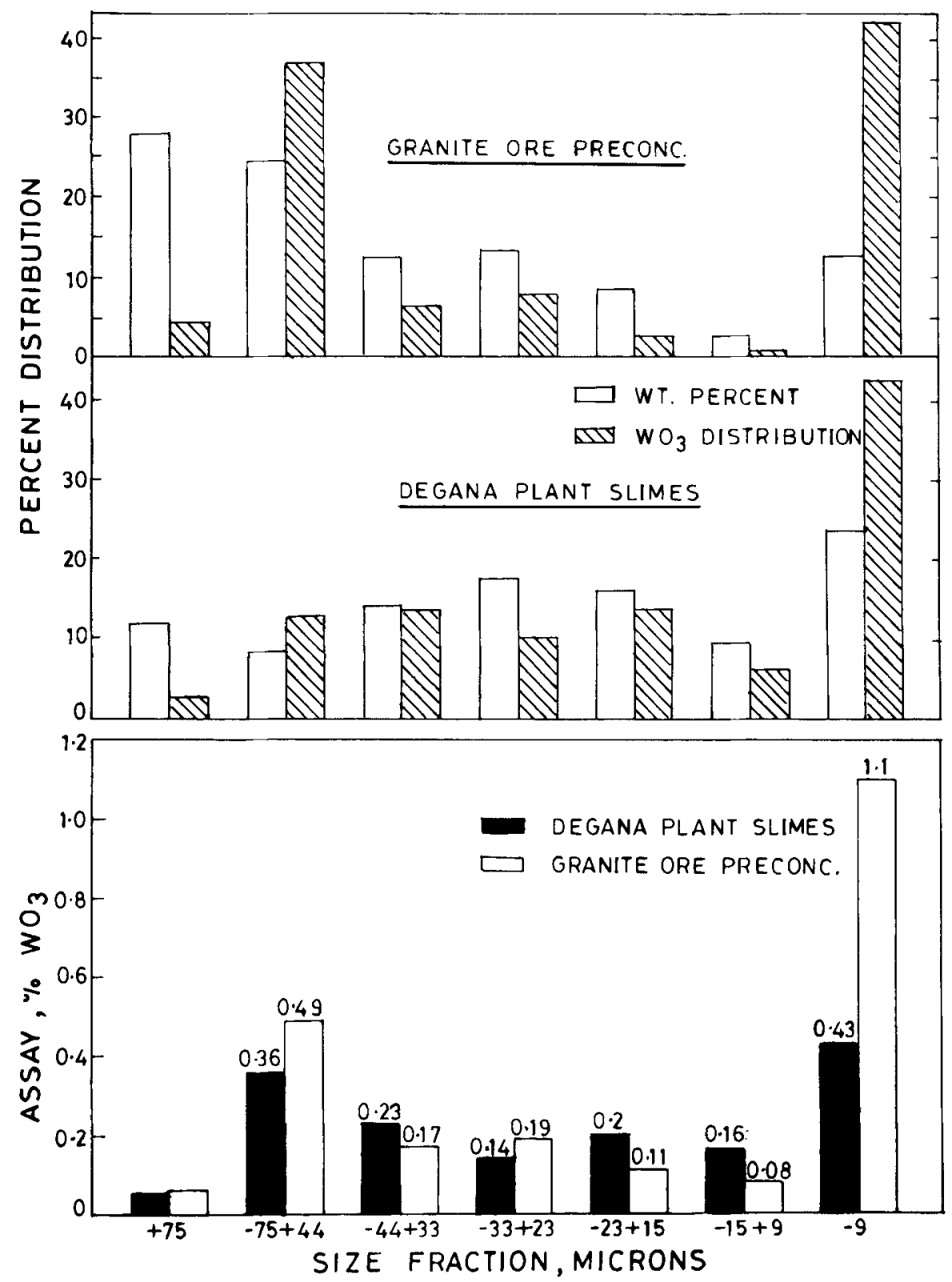

Figure 12. Relative distribution (percent by weight) of $\mathrm{WO}_{3}$ values in various size fractions for samples of Degana plant slimes and granite ore preconcentrate (BARC); relative enrichment of $\mathrm{WO}_{3}$ is observed in $-75+44$ microns and -9 microns fractions; more than $40 \%$ of values distributed in -9 microns size fraction (After Pradip 1991).

tails containing $60-65 \%$ of $\mathrm{WO}_{3}$ values and assaying $0.33 \% \mathrm{WO}_{3}$ were obtained as granite ore preconcentrate (Shukla et al 1988). The aforementioned two slimes samples represent two kinds of ore mineralogies available at Degana, depending on whether the quartz vein lode ore or the granite ore is processed in the plant. A comparison of the mineralogy of these two slime precursor ores is presented in table 6 . 


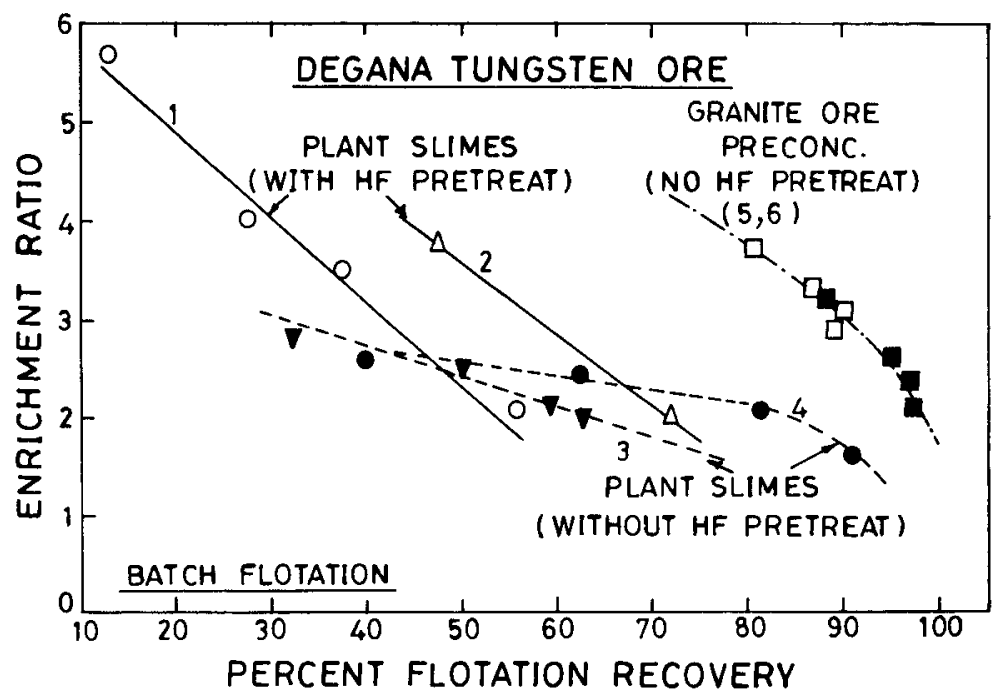

\begin{tabular}{|c|c|c|c|c|c|c|c|}
\hline \multirow{2}{*}{ Curve } & \multicolumn{5}{|c|}{ Reagent Dosage, $\mathrm{Kg} / \mathrm{t}$} & \multirow{2}{*}{\multicolumn{2}{|c|}{$\begin{array}{l}\text { Cond } \\
\text { H Time } \\
\text { Min. }\end{array}$}} \\
\hline & Na Silicate & $\begin{array}{l}\text { Na Fluo } \\
\text { silicate }\end{array}$ & $\begin{array}{l}\mathrm{Na-} \\
\mathrm{HMP}\end{array}$ & $\begin{array}{c}\mathrm{Na}^{-} \\
\text {Oleate }\end{array}$ & $\begin{array}{c}\text { K-Octyl } \\
\text { HXM }\end{array}$ & & \\
\hline 011 & $5 \cdot 3$ & - & - & $1 \cdot 6$ & - & 3.5 & 5 \\
\hline II & $2 \cdot 7$ & - & $5 \cdot 3$ & $1 \cdot 3$ & - & $3 \cdot 6$ & 5 \\
\hline$\Delta 2 \quad$ II & $\begin{array}{l}4 \\
2\end{array}$ & - & $\overline{1}$ & $\begin{array}{c}2 \cdot 3 \\
2\end{array}$ & - & $\begin{array}{l}3.5 \\
3.8\end{array}$ & $\begin{array}{l}5 \\
5\end{array}$ \\
\hline $\begin{array}{l}73 \\
-4\end{array}$ & - & $\begin{array}{l}5 \cdot 3 \\
5 \cdot 0\end{array}$ & - & $\begin{array}{c}2.5 \\
1\end{array}$ & $-\overline{4}$ & $\begin{array}{l}3.75 \\
4.9\end{array}$ & $\begin{array}{r}5 \\
15\end{array}$ \\
\hline$\square 5$ & - & $2 \cdot 3$ & - & - & 1.1 & 8.7 & 15 \\
\hline 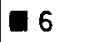 & - & $5 \cdot 3$ & - & $2 \cdot 0$ & - & $4 \cdot 2$ & 5 \\
\hline
\end{tabular}

Figure 13. A comparison of batch flotation test results obtained for Degana plant slimes with those obtained for granite ore preconcentrate sample from BARC; the beneficial effect of $\mathrm{HF}$ pretreatment is also shown in the figure (After Pradip 1991).

Size-wise assay and $\mathrm{WO}_{3}$ distribution for the two slimes samples is compared in figure 12. Two distinct peaks are observed, namely, enrichment of $\mathrm{WO}_{3}$ values in $-75+44$ microns and -9 microns size fractions. It is interesting-and disheartening - to note that more than $40 \%$ of total $\mathrm{WO}_{3}$ values are distributed in -9 microns fraction. While $\mathrm{WO}_{3}$ values in relatively coarser size fractions can possibly be recovered by fine gravity separation devices like Bartles Mozley concentrator and multi-gravity separator, recovery in the -9 microns size fraction is evidently a more difficult task. Efforts were made to concentrate these slimes by selective flocculationdispersion technique but due to unavailability of appropriate selective reagents, applicability and utility of this approach could not be ascertained (Pradip 1991).

Flotation tests carried out on these slimes samples, however, yielded more encouraging results. The results are summarized in figure 13 . Two reagents, namely alkyl hydroxamates and sodium oleate were used. The flotation performance (enrichment ratio vs recovery) of granite ore preconcentrate sample was found to be distinctly superior to that of Degana plant slimes sample. One of the reasons could be the deterioration in the surface properties of slimes sample due to prolonged storage 

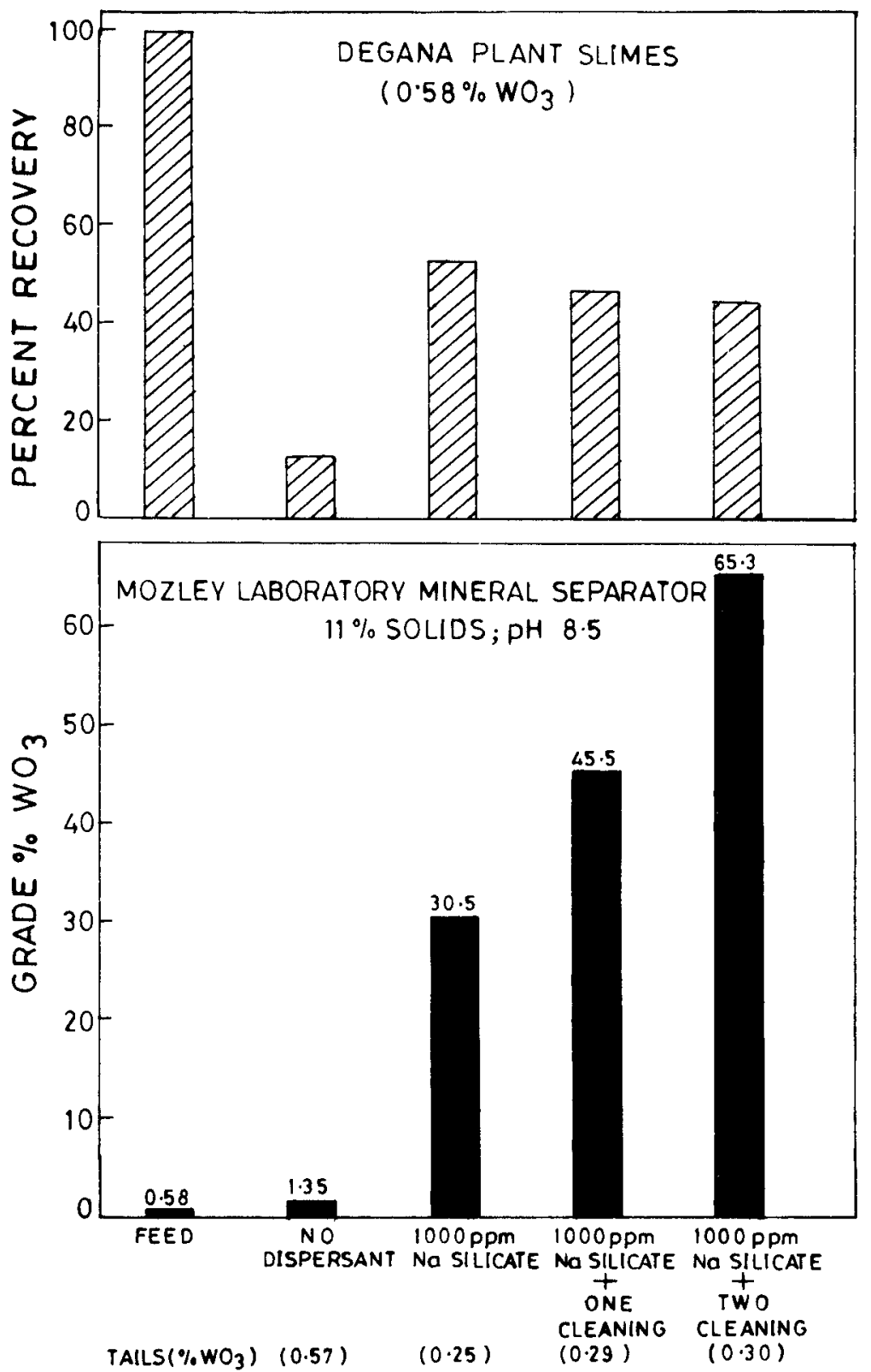

Figure 14. Recovery and grade of the wolframite concentrates produced on a Mozley Laboratory Mineral Separator from a sample (assay $0.58 \% \mathrm{WO}_{3}$ of Degana plant slimes: beneficial effect of sodium silicate dispersant illustrated in the figure (Data taken from Menaria $19911)$.

in the on-site ponds. In fact, hydrofluoric acid scrubbing (HF pretreatment) prior to flotation led to a remarkable improvement in its flotation performance as illustrated in figure 13. Due to the nonavailability of adequate sample of granite ore preconcentrate, the effect of HF pretreatment on its flotation could not be studied. The preliminary flotation results, i.e., enrichment ratio of 3-4 at flotation recoveries of $50-90 \%$, do 
indicate that flotation separation of slimes as and when the beneficiation plant becomes operational must be explored thoroughly with these and other selective reagents. With a proper combination of depressant-dispersant-collector along with optimized number of cleaning stages, it should be possible to recover a significant proportion of the values in slimes.

Another interesting observation regarding the possibility of recovering $\mathrm{WO}_{3}$ values from 'Degana plant slimes' sample is reported by Menaria (1991). In a collaborative investigation with Hindustan Zinc Ltd., it was observed that as high as $45 \%$ values could be recovered at a grade of $65 \% \mathrm{WO}_{3}$ starting from a sample assaying $0.58 \%$ $\mathrm{WO}_{3}$ using Bartles Mozley laboratory mineral separator. The remarkable effect of sodium silicate dispersant on enhancing the selectivity of separation is illustrated in figure 14. Since size wise recovery data is not available, it is not clear as to what proportion of $\mathrm{WO}_{3}$ values in the crucial -9 micron fraction are recovered. With proper optimization of gravity separation units within the plant, a significant proportion of $\mathrm{WO}_{3}$ values will be recovered in the operating plant, certainly in relatively coarser size range and it is expected that slimes from a running plant will not assay as high as $0.58 \% \mathrm{WO}_{3}$. It is interesting to note that the tails of laboratory mineral separator during these tests assay around $0 \cdot 3 \%$, indicating that gravity separation alone is not sufficient to treat slimes. These results thus emphasize the need to explore flotation separation and/or other fine particles processing techniques described in earlier sections of this paper, for the recovery of tungsten values from slimes.

\section{Conclusions}

A significant fraction of tungsten values are currently discarded as slimes during the conventional processing (gravity separation-sulphide flotation-magnetic separation) of tungsten ores, particularly those containing wolframite (relatively more friable and less amenable to flotation). Recent developments in gravity concentration (e.g. Bartles Mozley, Crossbelt and multi-gravity separators) as well as in HGMS equipment design have been utilized to recover relatively coarser particles of tungsten ore slimes.

Encouraging results have been reported on froth flotation of tungsten ore slimes using highly selective flotation collectors (such as those based on hydroxamic, arsonic and phosphonic acids, nitroso-napthols and sulpho-succinamates). Amongst the relatively novel techniques, shear flocculation using oleate and spherical agglomeration using phosphonic acids/oleate/amines appear to be quite promising. Development of highly selective reagents (selective flocculants, dispersants, depressants, and flotation collectors) is vital for the success of all fine particle processing schemes. Froth flotation with appropriate reagents combination could be one of the more promising means of recovering tungsten values from Indian ore slimes.

\section{Acknowledgements}

The author is grateful to Prof. E C Subbarao for his keen interest, encouragement and help and to the Department of Mines, New Delhi for financial support during the course of this work. 


\section{References}

Abeidu A M 1974 J. Mines Metals Fuels 22107

Abeidu A M 1975 Trans. Inst. Min. Met. 84 C5

Anon 1994 Indian Minerals Yearbook 2795

Auge $\mathrm{r}$, Bahr A and Koser H 1975 Proceedings, 1/th International mineral processing congress, Cagliari p. 26 Babok V K and Viduetskii M B 1967 USSR Patent No. 202020

Berger G S. Gak T L. Baishulakov A A and Bektasova M A 1982 Kompleksn Ispol'z Miner Syrya 914 [CA No. 98: $111273 \mathrm{j}$ and $96: 184871 \mathrm{w}]$

Bhaskar Raju, Subramanyam T V. Sun Z and Forsling W 1991 Int. J. Mineral Processing 32283

Bilsing U, Gruner H and Davies P 1985 Great Britain Patent GB 2159138

Bogdanov O S, Yeropkin Y I, Koltunova T E, Kobotova N P and Shtchukina N E 1974 Proc. X int. min. proc. congress, London (ed.) M J Jones (UK: IMM Pub.I p. 553

Burt R O 1984 in Gratity concentration technology (ed.) R O Burt (Amsterdam: Elsevier) Chapt. 28 p. 521 Burt R O 1988 Production and processing of fine particles (ed.) A J Plumpton (UK: Pergamon Press) p. 375 Chen Q R and Xu J $1980 Y u$ Se Chin Shu 3233 [CA No. 94-195525w]

Chin P C, Wang Y T and Sun Y P 1981 Developments in mineral processing series (ed.) J Laskowski (Amsterdam: Elsevier) 2 p. 1398

Clemente D, Newling P. Botelho de Sousa A, Lejeuvre G. Barber S P and Tucker P 1993 Mineral Eng. 6831

Collins D N, Wright R and Watson D 1984 Reagents in the minerals industry (eds) M J Jones and R Oblatt (London: IMM) p. 1

Dawei W, Keron W and Jicun Q 1986 Int. J. Mineral Processing 7361

Dawei W, Kewu W and Jicun Q 1987 Int. J. Mineral Processing 2035

Fuerstenau D W 1980 Fine particles processing (ed.) P Somasundaran (New York: AIME) 1 p. 669

Fuerstenau M C and Fitzgerald J J 1990 Advances in coul and mineral processing (eds.) S Chander and R R Klimpel (Colorado: AIME) Chapt 21 p. 193

Fuerstenau D W and Pradip 1984 Reagents in the minerals industry (eds) M J Jones and R Oblatt (UK: IMM Pub.) p. 161

Gak T L, Baishulakov A A and Gutsalyak T G 1983 Izu Vyssh Ucheb Zaved Tsvet Metul No 2 16 [CA:99:8714a]

Gak T L, Gutsalyak T G and Ni L. P 1981 Ispol'z Miner Syiya 217 [CA No 95:65689m]

Gak T L, Varalamov V G, Abdulkhairov S G. Aitaleeva S G and Frizen G Y 1985 Kompleksn Ispol'z Miner Syrya 933 [CA: 104-92684t]

Golikov W, Meixner M, Goerlach H, Hebel A, Voigt B, Seidel H, Hoefer H and Heidel R 1986 East German Patent, DD 233.311 [CA: 105 064225w]

Gruner $\mathrm{H}$ and Bilsing $\mathrm{U} 1989$ Comparison of the flotation behaviour of wolframite and cassiterite using 2-phenyl ethylene phosphonic acid (SPA). Plaistere and Hanger Intl Ltd. Technical Data Sheet Literature

Gruner H and Bilsing U 1992 Minerals Engg. 5429

Hanna H S and Somasundaran P 1976 Flotation - A M Gaudin Memorial Volume (ed.) M C Fuerstenau (New York: AlME) Chapt 8 p. 197

Harris P M and Humphreys D S C 1983 Tungsten: A review (London: IIM Pub.) p. 42

Hoefer H, Heidel R, Goerlach H and Lawrentjev A 1989 East German Patent DD 272419 [CA 112:161705e]

Houot R 1965 Sciences Terre Mem No 7 pp 96

Hu W and Li S 1989 Innovation in Slime Processing: I Tungsten Ore Slime Concentration SME - Preprint Number 89-67 3 pp

Hu Y and Wang D 1991 Proceedings XVII int. mineral processing congress, Dresden Germany' (Freiberg: Bergakademie) p. 97

Hu W B, Wang D Z and Qu G Z 1988 Proceedings $X$ V'l int. mineral processing congress (ed.) K S E Forssberg (Amsterdam: Elsevier) p. 445

Itoh S and Okada T 1980 Tohoku Kogyo Gijutsu Shikensho Hohoku 1129 [CA No 93-135670j]

Jakhu M R and Ray S 1996 Bull. Mater. Ssi. 19313

Kelsall G H and Marnakis K T 1984 Reagents in the mineral industry (eds) M J Jones and R Oblatt (UK: IMM Pub.) p. 25

Kelsall G H and Pitt J L 1987 Chemical Engy. Sci. 42679

Kirchberg H and Wottgen E 1967 Cassiterite flotation chemistry physics and applications of surface actice substances (ed.) C Paquot (London: Gordon and Breach) 3 p. 693 
Koh P, Andrews J and Uhlhen P 1986 Int. J. Mineral Processing 1745

Koltunova T E, Ryaboi V I and Yanis N A 1971 Obogashch Rud 1621

Kotlyarevsky I L, Alferiev I S, Krasnukhina A V, Pomazov V D and Egorov N V 1984 Reagents in the minerals industry (eds) M J Jones and R Oblatt (London: IIM Pub.) p. 173

Koval E M 1982 Obogaskh Rud (Leningrad) 27 14 [CA No. 99:74460n]

Laskowski J S and Ralston J 1992 (eds) Colloid chemistry in mineral processing (Amsterdam: Elsevier) pp 428

Leaver E S and Royer M B 1938 Flotation and recovery of scheelite from slimed material, USBM TP 585

Li B, Jin H. Huang K and Huang Y 1980 Yusechin Shu 3248 [CA 95:173146s]

Marinakis K I and Kelsall G H 1985 J. Colloid and Interface Sci. 106517

Marinakis K I and Kelsall G H 1987a Colloids and Surfaces 26243

Marinakis K I and Kelsall G H 1987b Colloids and Surfaces 25369

Marinakis K I and Kelsall G H 1987c Trans. IMM 96 C63

Matsuev L P 1966 Tr. Vsev Nauch Issled Inst Zolota Metall 25477

Mayby M R P 1992 Metals and minerals annual review (UK: Mining Journal Pub.) p. 72

McLaren D C 1942 Canadian Mining J.

Menaria K L 1991 Final Progress Report on Development of Selective Flocculation Technology for Recovery of Fine Mineral Particles, Department of Mines, New Delhi

Mercade Ven 1983 Eng. \& Mining J. 18452

Mitchell W Jr, Sollenberger C L and Kirkland T B 1951 Trans. AIME 19060

Mozley R H and Childs G J C 1992 The use of high ' $g$ ' forces to improve both classification and concentration in fine mineral processing. Invited talk presented at 46th Annual technical meeting of Indian Institute of Metals pp 13

Mukai S 1962 Mem. Fac. Engg. Kyoto University 24270

Myasnikova G A and Krasnikova N A 1971 Some collectors for the flotation of huebnerite-wolframite ores (Russian) [CA 79:8245]

Oliveira I F and Sampaio I A 1988 Production and processing of fine particles (ed.) A J Plumpton (UK: Pergamon Press) p. 209

Plaksin I N, Myasnikova G A and Krasnikova N A 1967 Flotation properties of rare metal minerals (ed.) I N Plaksin, Translated by R E Hammond (New York: Primary Sources) p. 1

Pradip 1981 Surface properties and flotation of rare earth ore minerals, $\mathrm{Ph} \mathrm{D}$ Thesis, University of California, Berkeley

Pradip 1990 Trans. IIM 40287

Pradip 1991 Development of Selective Flocculation Technology for Recovery of Tungsten Values from Slimes, Final Project Report, Department of Mines, New Delhi pp 186

Pradip and Chaudhuri N C 1996 Trans. Indian Institute of Metals, (in press)

Pradip and Fuerstenau D W 1991 Int. J. Mineral Processing 321

Rao G V and Gouri Charan T 1991 Proceedings international symposium on beneficiation and agglomeration (Bhubaneshwar: RRL) p. 590

Rao N K 1996 Bull. Mater. Sci. 19201

Senior G D and Poling G W 1986 Advances in mineral processing (ed.) P Somasundaran (New York: SME-AIME) Chapt 13 p. 220

Shukla S K. Manmadha Rao M, Subrahmanyam N P S, Iyer N V and Rao N K 1988 Laboratory Investigations on Recovery of Wolframite Ore from Low Grade Granite Ore from Degana Rajasthan, BARC Report 1408

Singh R. Pradip and Sankar T A P 1992 Int. J. Mineral Processing 36283

Somasundaran P 1986 Mineral processing at a crossroads problem and prospects (eds) B A Wills and R W Barley (Dordrecht: Martinus Nijhoff Pub.) p. 1

Stafford P T 1985 Mineral facts and problems, USBM Bulletin 675, p. 881

Subrahmanyam T V and Forssberg K S E 1990 Int. J. Mineral Processing 30265

Sun S, Chen Q and Yue Y 1984 Proceedings mineral processing extractive metallurgy conference (eds) M J Jones and P Gill (London: IMM Pub.) p. 521

Svoboda J 1987 Magnetic methods for the treatment of minerals (Amsterdam: Elsevier) p. 692

Tiunov A A, Zakhanov L I and Tiunov Y A 1980 Tsvetn. Met. 1268 [CA No. 94:107059u]

Vazquez L A, Ramachandran S and Grauerholz N L 1976 Flotation-A M Gaudin Memorial Volume (ed.) M C Fuerstenau. (New York: SME-AIME) Chapt 21 p. 580

Vishwanathan K V and Mazumdar K K 1972 Adsorption of Long Chain of Electrolytes at Solid-Liquid Interface Part III - Wolframite-Water System BARC Report No 603 Bhabha Atomic Research Centre, India. p. 20 
Wang D, Hu Y and Hu W 1986 Zhongnan Kuangye Xue Yuan Xuebao 440 [CA: 107:180638y]

Warren L J 1975a Trans. IMM 84 C99

Warren L J 1975b J. Colloid Interface Sci. 50307

Warren L J 1982 Colloids and Surfaces 5301

Warren L J 1992 Colloid chemistry in mineral processing (ed.) J S Laskowski and J Ralston (Amsterdam: Elsevier) p. 309

Wells I S 1986 Operational experience with boxmag rapid high intensity wet magnetic separator, Presented at colloquium on magnetic separation in mineral industry (referred to in the monograph by Svoboda $J$ 1987 p. 540 )

Woo J C and Whang K V 1986 J. Korean Inst. Mineral and Mining Engrs. 2398

Yih S W H and Wang C T 1981 Tungsten-sources, metallurgy, properties and application (New York: Plenum Press) pp 1-126

Yongxin L and Changger L 1983 Int. J. Mineral Processing 10205 and 219

Zhu J and Jiang S 1983 Youse Jinshu 3532 [CA 101:26582u]

Zhu J and Jiang S 1986 Zhongnan Kuangye Xueyuan Xuehao 129 [CA:105:82795m)

Zhu Y and Xiao Y 1989 Xiyou Jinshu 818 [CA 112:60132k]

Zhu J and Zhu Y 1984 Zhongnan Kuangye Xueyuan Xuebao 323 [CA $101: 134673$ ] ] 